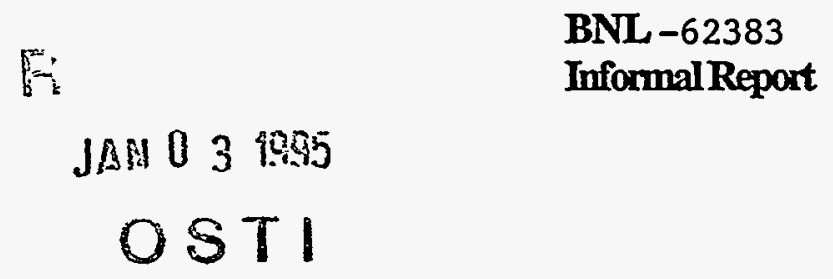

\title{
ENGINEERING ANALYSIS OF THE USE OF COMPRESSION REFRIGERANTS IN THE THIN POLYMER ICEMAKER
}

\section{RICHARD LEIGH AND JOHN ANDREWS}

NOVEMBER 1995

Prepared for:

Office of Utility Technologies

Utility Systems Division

U.S. Department of Energy

Washington, DC 20585

\section{Energy Efficiency and Conservation Division DEPARTMENT OF APPLIED SCIENCE}

BROOKHAVEN NATIONAL LABORATORY UPTON, LONG ISLAND, NEW YORK 11973
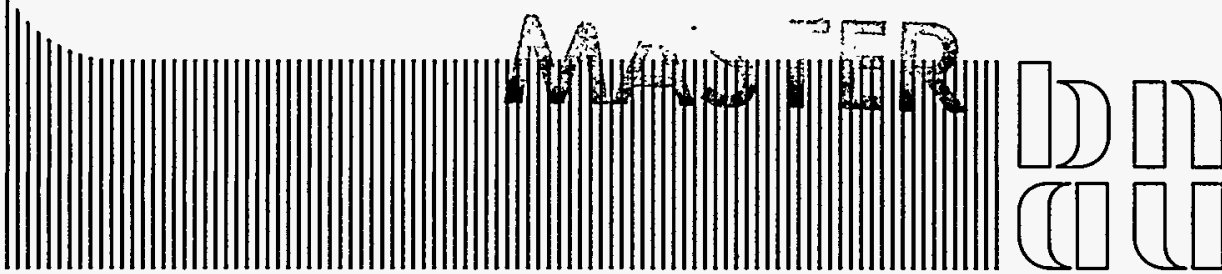


\title{
ENGINEERING ASSESSMENT OF THE USE OF COMPRESSION REFRIGERANTS IN THE THIN POLYMER ICEMAKER
}

\section{RICHARD LEIGH AND JOHN ANDREWS}

NOVEMBER 1995

\author{
Prepared for: \\ Office of Utility Technologies \\ Utility Systems Division \\ U.S. Department of Energy \\ Under Contract No. DE-AC02-76CH00016
}

\author{
Brookhaven Nátional Laboratory \\ Upton, New York 11973
}

\section{DISCLAIMER}

This report was prepared as an account of work sponsored by an agency of the United States Government. Neither the United States Government nor any agency thereof, nor any of their employees, makes any warranty, express or implied, or assumes any legal liability or responsibility for the accuracy, completeness, or usefulness of any information, apparatus, product, or process disclosed, or represents that its use would not infringe privately owned rights. Reference herein to any specific commercial product, process, or service by trade name, trademark, manufacturer, or otherwise does not necessarily constitute or imply its endorsement, recommendation, or favoring by the United States Government or any agency thereof. The views and opinions of authors expressed herein do not necessarily state or reflect those of the United States Government or any agency thereof. 


\begin{abstract}
In previous studies we have developed the concept of an ice-making device constructed of thin polymer films, arranged so that when filled with a cold fluid they expand in a set of parallel tubes, on the exterior of which ice forms. When the ice is about one millimeter thick, the cold fluid is removed from the tubes and they collapse, being pulled away from the ice by a vacuum within. The device has been successfully demonstrated in a version where the tubes are filled with a water-ethylene glycol brine. This was followed by an economic assessment which indicated that the device would be even more competitive with existing systems if the compression refrigerant itself were admitted into the polymer film structure on which the ice forms. This report presents an engineering study of such a system, examines the outstanding questions which must still be answered and assesses the potential economics of the system.

We develop preliminary designs for systems using R-134a and R-C318 as refrigerants which satisfy code requirements. We use standard thermodynamic and heat transfer analysis to determine expected performance for the systems, and combine this with component and assembly cost estimates to prepare life-cycle costs for the two new systems. Comparing them to commercially available systems, we find that these "polymer evaporator" systems seem to be completely feasible technically and that if they are successfully demonstrated, they should have substantial economic advantages over existing ice-making devices.
\end{abstract}


1. INTRODUCTION AND SUMMARY $\ldots \ldots \ldots \ldots \ldots \ldots \ldots \ldots$

2. PHYSICAL/CHEMICAL REFRIGERANT SCREENING $\ldots \ldots \ldots \ldots \ldots 3$

3: THERMODYNAMIC PROPERTIES OF SELECTED REFRIGERANTS $\quad \therefore \ldots 7$

4. PRELIMINARY SYSTEM DESIGN $\ldots \ldots \ldots \ldots \ldots \ldots \ldots \ldots \ldots$

4.1 Preliminary Design Parameters $\ldots \ldots \ldots \ldots \ldots \ldots \ldots$

4.2 Preliminary Design for $\mathrm{R}-134 \mathrm{a} \ldots \ldots \ldots \ldots \ldots \ldots \ldots$

4.3 Preliminary Design for $\mathrm{R}-\mathrm{C} 318 \ldots \ldots \ldots \ldots \ldots \ldots \ldots \ldots \ldots$

5. SYSTEM MODELLING AND EXPECTED EFFICIENCY $\ldots \ldots \ldots \ldots 13$

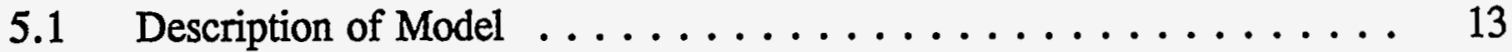

5.2 System Modelling with $\mathrm{R}-134 \mathrm{\ldots} \ldots \ldots \ldots \ldots \ldots \ldots \ldots \ldots$

5.3 System Modelling with $\mathrm{R}-\mathrm{C} 318 \ldots \ldots \ldots \ldots \ldots \ldots$

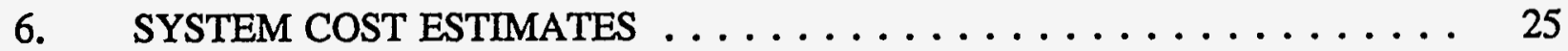

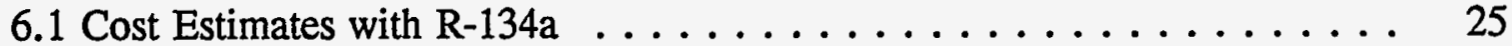

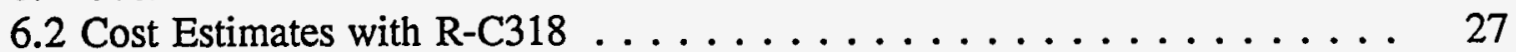

Appendix A: Refrigerants with no Chlorine or Bromine

Appendix B: Storage Tank Calculations

Appendix C: Pad Design Calculations

Appendix D: Pipe Sizing Calculations for R-134a

Appendix E: Pipe Sizing Calculations for R-C318

Appendix F: Economic Analysis for R-134a

Appendix G: Economic Analysis for R-C318 



\section{FIGURES}

Figure 3-1: Temperature-Entropy Equilibrium Curve of R-C318.

Figure 4-1: Stress-pressure relations.

Figure 4-2: Thin Polymer Ice Maker and Tank: Conceptual Design. 11

Figure 5-1: Ice Maker System Diagram. $\quad 13$

Figure 5-2: Heat Flow in Ice Building.

Figure 5-3: Analysis of Ice-Building Operation with R-134a. $\quad 15$

Figure 5-4: Analysis of Water-Chilling Operation with R-134a. 16

Figure 5-5: Analysis of Ice-Building Operation with R-C318. 20

Figure 5-6: Analysis of Water-Chilling with R-C318.

Figure 5-7: Ice Maker Superheated System Diagram. 19

Figure 5-8: Analysis of Ice Building with Superheated R-C318. 22

Figure 5-9: Analysis of Water Chilling with Superheated R-C318. 23

\section{TABLES}

Table 1-1: Comparison of System Economics.

Table 2-1: Refrigerants having no chlorine or bromine.

Table 2-2: Chemical and Hazard Characteristics of Candidate Refrigerants. 5

Table 6-1 Electricity Rate Structure.

Table 6-2: Component Costs for Polymer Film Ice Maker. 26

Table 6-3: Economic Characteristics of the Polymer Ice Maker, R-134a. 27

Table 6-4: Economic Characteristics of the Polymer Ice Maker, R-C318. 28 



\section{INTRODUCTION AND SUMMARY}

A new device for the production of ice has been designed, constructed and tested ${ }^{1}$ in a project that is part of the District Heating and Cooling program at Brookhaven National Laboratory. The central feature of this ice maker is a set of tubes made of a thin polymer film. Cold fluid within the tubes causes ice to form on the outside of the tubes, and when the coolant is removed the resulting vacuum causes the tube to collapse and pull away from the ice, which is then free. This system obviates the reheat cycles necessary in existing ice makers, and so offers the potential for higher efficiency.

A subsequent part of this project, an economic assessment of this device ${ }^{2}$ showed that it has the potential to gain a significant share of the market for energy-related ice making systems. Such systems include slush ice production for district cooling and ice production for cold storage systems in buildings.

However, that study also showed that the icemaker's efficiency could be significantly improved. In the tested version, a chiller cools a brine to subfreezing temperatures in a separate evaporator, and the brine is subsequently pumped through the ice making pad. This extra stage of heat exchange leads to higher temperature differences and more work for the compressor, resulting in a higher electric bill and greater capital costs than would otherwise be necessary. If, alternatively, the refrigerant could be allowed to evaporate directly inside the thin polymer ice maker itself, the evaporator temperature would be raised by several degrees, resulting in a substantial increase in system COP and capacity.

In this report we examine the feasibility of this scheme. The choice of refrigerants is increasingly constrained by concerns about the ozone layer; the chemical compatibility of the refrigerants and the polymers must be assured, and most important, the design must ensure that the relatively fragile polymer icemaker is not burst by the pressurized refrigerant. All these questions are addressed in the sections that follow, where a conceptual design is advanced, two candidate refrigerants (R-134a and R-C318) are selected, the systems are analyzed technically and then, using the exact formulation of our earlier study ${ }^{2}$, assessed economically. We believe both the design and the economic assessment to be quite conservative.

In Table 1-1, the resulting data on the two "Advanced Polymer" systems is presented in the top rows, while the data for the competitive systems has been imported directly from our economic assessment ${ }^{2}$. "Polymer/Brine" is our design study based directly on our experimental apparatus. The "Flat Plate" and "Tubular Evaporator" represent commercially available systems, and accurately indicate the current costs of ice storage systems (in 1992 dollars). The "direct contact" concept is a more advanced and as yet unavailable system in which the refrigerant actually mixes with the system water. Since this system constantly loses refrigerant to the system water, it is unlikely to achieve commercial success. The table makes it clear that the advanced polymer ice maker should be very competitive against existing systems, and that a laboratory test of this concept would be a very worthwhile investment. 
Table 1-1: Comparison of System Economics.

\begin{tabular}{|l|c|c|c|c||}
\hline System Type & Status & $\begin{array}{c}\text { Capital } \\
\text { Outlay } \\
(\$ 1000)\end{array}$ & $\begin{array}{c}\text { Electric } \\
\text { Bill } \\
(\$ 1000 / \text { mnth })\end{array}$ & $\begin{array}{c}\text { Net Present } \\
\text { Value } \\
(\$ 1000)\end{array}$ \\
\hline \hline Polymer/R-C318 & Design & 304 & 4.5 & 457 \\
\hline Polymer/R-134a & Design & 332 & 4.3 & 480 \\
\hline Polymer/Brine & Demo & 340 & 9.9 & 553 \\
\hline Flat Plate & Com.Av. & 316 & 10.0 & 524 \\
\hline Tubular Evaporator & Com.Av. & $372-382$ & 8.7 & $550-560$ \\
\hline Direct Contact & Demo. & $215-300$ & 9.9 & $410-490$ \\
\hline
\end{tabular}




\section{PHYSICAL/CHEMICAL REFRIGERANT SCREENING}

Environmental and other constraints will restrict the choice of refrigerants to a small subset of the several dozen known candidates. Consideration of current threats to the ozone layer will lead us to eliminate all candidates containing chlorine and bromine; the chemical compatibility of the refrigerants and the polymers must be assured, as well as the impermeability of the polymer to that refrigerant; finally, levels of toxicity and flammability must be taken into account. In this section we work through these steps in turn.

Several sources of general information on compression refrigerants provide useful data. We start with a reference ${ }^{3}$ listing 86 standard refrigerants, but do not reproduce the entire table here in the interest of brevity.

In the foreseeable future, the choice of refrigerants will be increasingly constrained by concerns about the ozone layer. CFC production is completely banned by Jan 1, 1996, according to the Montreal Protocol. In addition, $90 \%$ of HCFC use is now slated to be phased out over the 1996-2015 period. ${ }^{4}$ Anticipating that these restrictions can only get stricter, we consider only those refrigerants known to be harmless in this regard; this essentially means that they can have no chlorine or bromine in them. The result of applying this filter to the 86 refrigerants mentioned above is Table $2-1$, which gives the refrigerant number and chemical formula of the 35 distinct candidates having no chlorine or bromine in them. (Table 2-1 is an abbreviation of Appendix A.)

Second, we are interested only in refrigerants that have reasonable working pressures at the evaporator temperature of $25^{\circ} \mathrm{F}\left(-4^{\circ} \mathrm{C}\right)$. The working pressure at $25^{\circ} \mathrm{F}$ must be greater than one atmosphere (so the flexible pad can expand) and yet of relatively modest pressure (so that it will not burst). The vapor pressures at $25^{\circ} \mathrm{F}$ (derived from boiling and critical parameters ${ }^{5}$ in Appendix A) of all sub-critical refrigerants are shown in Table 2-1. Also, any material with a critical temperature below $25^{\circ} \mathrm{F}$ is unsuitable, and for these substances the critical temperature is shown in Table $2-1$, as " $\mathrm{T}_{c}=-150^{\circ} \mathrm{F}$ ", rather than the pressure at $25^{\circ} \mathrm{F}$, which is indeterminate. The candidates with working pressures between one and five atmospheres are presented in Table 2-2, along with various compatibility criteria.

Pressures will be further constrained by the ASME code for pressure vessels, ${ }^{6}$ which requires that refrigerant vessels be capable of withstanding seven times their operating pressure. Exactly how this will be applied will depend on detailed design considerations, which will be developed in later sections.

Third, the chemical compatibility of the refrigerants and the polymers and metals must be assured. Detailed data on the chemical compatibility has been difficult to find. Limiting ourselves to the PFA teflon from which the demonstration ice makers have been constructed, we will rely on the widely-known resistance of this material to acids, alkalies, oxidizers, oils and fuels and hydrocarbons ${ }^{7}$ and organic solvents ${ }^{8}$ to assume that chemical compatibility will not be a problem. Immersion creep testing ${ }^{9}$ would be an early step in an experimental program. 
Table 2-1: Refrigerants having no chlorine or bromine.

\begin{tabular}{|c|c|c|c|c|c|}
\hline \multicolumn{2}{|c|}{ Halocarbons: } & \multirow{2}{*}{$\begin{array}{c}P @ 25^{\circ} \mathrm{F} \\
\mathrm{T}_{\mathrm{c}}=-50\end{array}$} & \multicolumn{2}{|c|}{ Hydrocarbons: } & \multirow{2}{*}{$\begin{array}{l}P @ 25^{\circ} \mathrm{F} \\
\mathrm{T}_{\mathrm{c}}=-117\end{array}$} \\
\hline 14 & $\mathrm{CF}_{4}$ & & 50 & $\mathrm{CH}_{4}$ & \\
\hline 23 & $\mathrm{CHF}_{3}$ & 22.7 & 170 & $\mathrm{CH}_{3} \mathrm{CH}_{3}$ & 22.1 \\
\hline 32 & $\mathrm{CH}_{2} \mathrm{~F}_{2}$ & 7.1 & 290 & $\mathrm{CH}_{3} \mathrm{CH}_{2} \mathrm{CH}_{3}$ & 4.2 \\
\hline 41 & $\mathrm{CH}_{3} \mathrm{~F}$ & 18.5 & 600 & $\mathrm{CH}_{3} \mathrm{CH}_{2} \mathrm{CH}_{2} \mathrm{CH}_{3}$ & 0.9 \\
\hline 116 & $\mathrm{CF}_{3} \mathrm{CF}_{3}$ & 16.4 & $600 \mathrm{a}$ & $\mathrm{CH}\left(\mathrm{CH}_{3}\right)_{3}$ & 1.3 \\
\hline 125 & $\mathrm{CHF}_{2} \mathrm{CF}_{3}$ & 5.5 & 610 & $\mathrm{C}_{2} \mathrm{H}_{5} \mathrm{OC}_{2} \mathrm{H}_{5}$ & 0.2 \\
\hline $134 a$ & $\mathrm{CF}_{3} \mathrm{CH}_{2} \mathrm{~F}$ & 2.5 & 611 & $\mathrm{HCOOCH}_{3}$ & 0.2 \\
\hline $143 \mathrm{a}$ & $\mathrm{CH}_{3} \mathrm{CF}_{3}$ & 5.4 & 630 & $\mathrm{CH}_{3} \mathrm{NH}_{2}$ & 1.1 \\
\hline $152 \mathrm{a}$ & $\mathrm{CH}_{3} \mathrm{CHF}_{2}$ & 2.3 & 631 & $\mathrm{C}_{2} \mathrm{H}_{5} \mathrm{NH}_{2}$ & 0.4 \\
\hline \multicolumn{3}{|c|}{ Cyclic Organic Compounds: } & \multicolumn{3}{|c|}{ Inorganic Compounds: } \\
\hline C318 & $\mathrm{C}_{4} \mathrm{~F}_{8}$ & 1.1 & 702 & $\mathrm{H}_{2}$ & $\mathrm{~T}_{\mathrm{c}}=-400$ \\
\hline \multicolumn{3}{|c|}{ Unsaturated Organic Compounds: } & 704 & $\mathrm{He}$ & $\mathrm{T}_{\mathrm{c}}=-450$ \\
\hline 1114 & $\mathrm{CF}_{2}=\mathrm{CF}_{2}$ & 15.7 & 717 & $\mathrm{NH}_{3}$ & 3.6 \\
\hline $1132 a$ & $\mathrm{CH}_{2}=\mathrm{CF}_{2}$ & 20.7 & 718 & $\mathrm{H}_{2} \mathrm{O}$ & $\mathrm{T}_{\mathrm{f}}=32$ \\
\hline 1141 & $\mathrm{CH}_{2}=\mathrm{CHF}$ & 13.4 & 720 & $\mathrm{Ne}$ & $T_{c}=-380$ \\
\hline 1150 & $\mathrm{CH}_{2}=\mathrm{CH}_{2}$ & 38.0 & 728 & $\mathrm{~N}_{2}$ & $T_{c}=-232$ \\
\hline \multirow[t]{3}{*}{1270} & $\mathrm{CH}_{3} \mathrm{CH}=\mathrm{CH}_{2}$ & 5.2 & 732 & $\mathrm{O}_{2}$ & $T_{c}=-181$ \\
\hline & & & 740 & $\mathrm{~A}$ & $T_{c}=-188$ \\
\hline & & & 744 & $\mathrm{CO}_{2}$ & 27.3 \\
\hline \multicolumn{3}{|c|}{ Temperature in ${ }^{\circ} \mathrm{F}$} & $744 a$ & $\mathrm{~N}_{2} \mathrm{O}$ & 28.4 \\
\hline \multicolumn{3}{|c|}{ Pressure in atmospheres } & 764 & $\mathrm{SO}_{2}$ & 1.3 \\
\hline
\end{tabular}

Several incompatibilities exist between refrigerants and metals ${ }^{10}$, and these are listed in Table 2-2. The first three refrigerants are halogenated and as such, should not be used with magnesium or zinc-bearing alloys here, where water could be present. A more serious problem is the tendency of ammonia (R717) to attack copper and copper-bearing alloys. This is not a problem within the compression chiller system itself, where copper can be avoided, but when an ice-making pad fails, refrigerant could be released into the building system water. If 
Table 2-2: Chemical and Hazard Characteristics of Candidate Refrigerants.

\begin{tabular}{|c|c|c|c|c|c|c|}
\hline $\begin{array}{l}\text { Refrig- } \\
\text { erant \# }\end{array}$ & $\begin{array}{l}\text { Incompatible } \\
\text { with: }\end{array}$ & $\begin{array}{c}\text { Explosive } \\
\text { Limits (vol.\%) }\end{array}$ & $\mathrm{Q}_{\mathrm{c}} / \mathrm{Q}_{\ell}$ & UL & $\begin{array}{c}\text { ANSI/ } \\
\text { ASHRAE }\end{array}$ & $\begin{array}{l}\text { OSHA } \\
\text { PEL } \\
\text { ppm }\end{array}$ \\
\hline $134 a$ & $\mathrm{Mg}, \mathrm{Zn}$ & none & 7 & & & A \\
\hline $152 a$ & $\mathrm{Mg}, \mathrm{Zn}$ & $3.7-20$ & 37 & & & A \\
\hline C318 & $\mathrm{Mg}, \mathrm{Zn}$ & none & 2 & & & A \\
\hline 1270 & & $2-11$ & 120 & & 1 & A \\
\hline 290 & & $2.1-9.6$ & 122 & $5 \mathrm{~b}$ & 1 & 1000 \\
\hline $600 \mathrm{a}$ & & $1.7-9.7$ & 110 & $5 b$ & 1 & - \\
\hline 630 & & $4.9-20.7$ & 38 & & 3 & 10 \\
\hline 717 & $\mathrm{Cu}$, Brass,... & $15-33$ & 15 & 2 & 3 & 50 \\
\hline 764 & $\begin{array}{c}\text { Water } \\
\left(->\mathrm{H}_{2} \mathrm{SO}_{4}\right)\end{array}$ & $\begin{array}{c}\text { Non- } \\
\text { flammable }\end{array}$ & 0 & 1 & 3 & 5 \\
\hline \multirow{2}{*}{\multicolumn{2}{|c|}{ Toxicity scales: }} & \multicolumn{2}{|c|}{ Maximum hazard: } & 1 & 3 & $->0$ \\
\hline & & \multicolumn{2}{|c|}{ Minimum hazard: } & 6 & 1 & $10^{6}$ \\
\hline
\end{tabular}

ammonia is used, it might be necessary to flush the system often to keep concentrations acceptably low. Even more serious is the conversion of sulfur dioxide (R764) into sulfuric acid on contact with water, which would occur whenever a pad failed. We have not identified any compatibility problems for the hydrocarbons (R1270, R290 and R600a) or for methyl amine (R630).

Fifth, the impermeability of the polymer to the refrigerant must be ensured. Here we have no data for any candidate refrigerants or for PFA teflon. We do know that related FEP Teflon will transmit 2.4 gram-moles ( 1.5 ounces) of water per square foot per year through a typical 5-mil film, and 5-10 gram-moles of gasses such as $\mathrm{O}_{2}, \mathrm{~N}_{2}$ or $\mathrm{CO}_{2}^{8}$ at a differential pressure of one atmosphere ${ }^{8}$. It would not be surprising if similar rates occurred for ammonia and sulfur dioxide, and lower rates for the larger molecules of the other candidates, but the only way to be sure is testing.

Sixth, safety issues must be considered; various attributes are shown in Table 2-2 for the candidate refrigerants. Arguing that these ice-makers will be used in large industrial applications where special measures can be taken, and that the whole refrigeration industry may be making similar difficult choices in the near future, we will not use either toxicity or 
flammability to eliminate candidates automatically. Table 2-2 gives a comparison of the hazards to life and the explosive limits for the same nine candidates.

The explosive limits ${ }^{5,11}$ refer to volumetric percentages; for a given leak, the wider the range, and the lower the lower limit, the more easily an explosion can be triggered. In the next column we compare the possible damage from such an accident across refrigerants by dividing the heat of combustion, $Q_{c}{ }^{5}$ (representing the energy released in a fire or explosion) by the latent heat of vaporization, $Q_{\ell}$, (representing the quantity of refrigerant needed for a given refrigeration capacity).

Three measures of toxicity are presented, with the scales explained on the bottom line. The ANSI/ASHRAE Standard 15-78 is an arbitrary measure based on "hazards involved in use". ${ }^{12}$ The Underwriters Laboratories classification ${ }^{13}$ is based on toxicity experiments with guinea pigs; "Group 1" materials produce lethal or serious injury after five minutes exposure at $0.5-1.0 \%$ concentrations, while "Group 6" materials appear to be benign, other than the possibility of suffocation. Finally, the U.S. Occupational Safety and Health Authority (OSHA) Permanent Exposure Limit (PEL) is given ${ }^{14}$ in parts per million, where such a limit has been defined. (These numbers refer to "time weighted averages" or "TWA's.) An "A" in this column means the substance is classified as a simple asphyxiant.

Screening based on this data, we discard R764 (sulfur dioxide) because of its tendency to form sulfuric acid and its high toxicity. R1270 (propylene), R290 (propane) and R600a (Isobutane) are dropped due to their high heats of combustion. The remaining five compounds fall into two groups: R-C318 (Octofluorocyclobutene) and R630 (methyl amine) with vapor pressures just above one atmosphere at $25^{\circ} \mathrm{F}$ and the remainder, R134a (tetrafluoroethane), R152a (difluoroethane) and R717 (ammonia) with higher vapor pressures which would require careful engineering of the pad to meet code requirements and avoid pressure-induced failures. We will choose one from each group for further analysis: R-C318 because of its non-explosive nature, low heat of combustion and lower toxicity, all when compared to R630, and R134a from the second group for essentially the same reasons. 


\section{3: THERMODYNAMIC PROPERTIES OF SELECTED REFRIGERANTS}

The pressure and temperature relations and other thermodynamic properties of the refrigerants are basic to the design of an ice making system. In this section we discuss data on the vapor pressure, enthalpy, entropy and other relevant properties of R134a and R-C318.

For R134a, a detailed program of measurement and analytic characterization has recently been carried out by Wilson and Basu ${ }^{15}$. The authors have made a Fortran program available which allows straightforward calculation of tables of all quantities needed for cycle analysis. The analytic representations include an expression for vapor pressure as a function of temperature with six adjustable constants, a four-constant expression for liquid density, a 13-constant MartinHou equation of state and a five-constant expression for the ideal gas heat capacity. The latter agrees with the expression in Daubert and Danner ${ }^{5}$ to better than one per cent. Values for pressure and changes in enthalpy and entropy derived from Wilson and Basu's equations also agreed with tabular data from ASHRAE ${ }^{16}$ to better than one per cent in the regimes relevant to our calculations.

Refrigerant C-318 (perfluorocyclobutane, $\mathrm{C}_{4} \mathrm{~F}_{8}$ ) has not been used commercially to our knowledge, and less technical data is available. Basic property data from Daubert and Danner ${ }^{5}$ was useful, but the virial equation of state was not sufficiently precise to generate values of enthalpy and entropy. One recent paper ${ }^{17}$ was rendered useless by typographical errors and an incomplete presentation. Older work by Tawfik Morsey ${ }^{18}$ proved far more useful. His extensions of the B-W-R equation of state explicitly guarantee a set of important thermodynamic constraints at the critical point. Programmed in a spreadsheet, Morsey's equation of state agreed to within one percent with that of Dauberg and Danner and with the extensive empirical data of Martin $^{19}$ (from which he had derived his constants). Temperature-entropy and temperatureenthalpy diagrams derived from Morsey's equations agreed to within graphical accuracy with figures in Cipollone's ${ }^{17}$ paper.

This last agreement is welcome confirmation of the somewhat peculiar behavior of C-318 in the temperature-entropy plane, shown in Figure 3-1: the saturated vapor side of the curve slopes sharply out to - the right. Since the compression part of the refrigeration cycle is (approximately) isentropic, this means that compression of saturated vapor will result in the formation of small amounts of liquid, probably in the form of a mist. In the cycle analysis to follow we deal with this unusual behavior in two different ways.

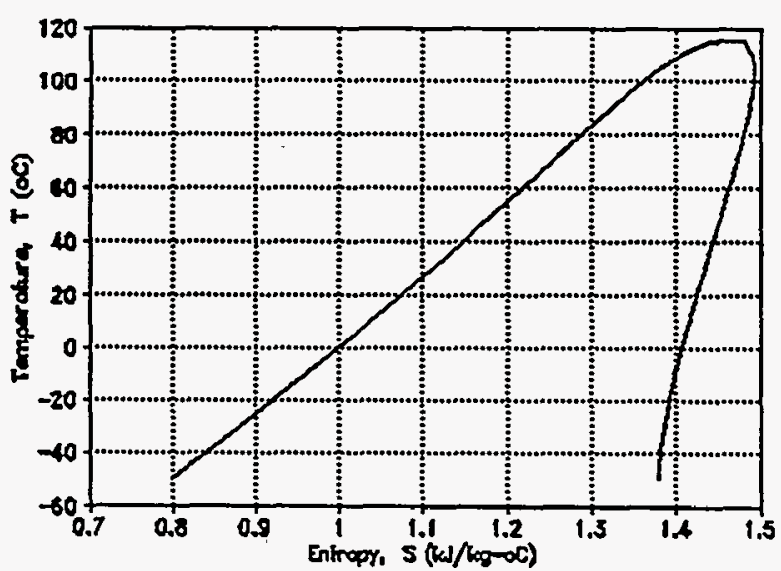

Figure 3-1: Temperature-Entropy Equilibrium Curve of R-C318. 


\section{PRELIMINARY SYSTEM DESIGN}

In this section we develop preliminary system designs which will serve as models in which to assess system performance and for which we develop cost estimates. Many details which would be included in an actual design are combined or included only in summary, but we have attempted to include enough detail to permit meaningful comparisons with the existing systems examined earlier and summarized in Chapter 1. Because there are significant differences between systems designed to operate on R-134a and on R-C318, we present them in separate sections.

\subsection{Preliminary Design Parameters}

The system design will follow the one developed for the New York climate during our economic assessment of the original (brine-filled) polymer ice maker ${ }^{2}$. The peak design-day load was taken as 500 tons, with a design-day load factor of 0.75 for the ten hours during which the system supplies cooling to a commercial building. The optimal system incorporated a 16,300 $\mathrm{ft}^{3}$ ice storage tank capable of storing 5520 ton-hours ${ }^{*}$ of ice. With this storage, an ice maker with a steady state capacity of 116 tons $(1.4 \mathrm{mmBtu} / \mathrm{hr}$ or 408 thermal kilowatts) was sufficient to operate the system through a fifteen week cooling season.

As discussed in Ref. 2, optimal operation for the system involved running the ice maker at all times, but using it in "cooling mode" when warm $\left(55^{\circ} \mathrm{F}\right)$ water was returning from the building distribution system, which we assumed occurred eight hours per day, during the peak electric rate period. With the pads suspended above the water in the tank, returning water is sprayed onto them and is cooled to about $45^{\circ} \mathrm{F}$ before dripping onto the tank. This allows the evaporator (the pads) to run at a considerably higher temperature (above $40^{\circ} \mathrm{F}$ ), and so lowers the power requirements of the compressor and the electric bills. When no warm water is returning, the pads are cooled below freezing and cold water is sprayed onto them. When ice has built up to perhaps a millimeter thick, the pads are deflated and the ice falls off and into the bath. This combined operating mode is commonly used in current commercial (rigid evaporator) ice making systems, and results in substantial savings in operating costs.

An apparent design obstacle with the thin polymer pad design is the limited strength of polymers, including the PFA used in our experiments. The internal pressure indicated in Table 2-1 for R-134a, 36 psia at $25^{\circ} \mathrm{F}$, is substantially higher than pressures exerted on the polymer tubes by the brine during previous testing of the icemaker. It is necessary to relate the differential pressure between the inside and the outside of the tubes making up the pad to the internal stresses in the polymer, and to compare these to the various characterizations of the strength of the material.

*. Note that a "ton" is the standard American unit of refrigeration power, equivalent to one ton of ice per day or $12,000 \mathrm{Btu} / \mathrm{hr}$, a "ton-hour" is $12,000 \mathrm{Btu}$ or $2000 / 24=83.3 \mathrm{lb}$ of ice. 
First, we consider the material characteristics. PFA has a listed "tensile strength" of $4000 \mathrm{psi}^{8}$. However, this is not a good basis for design since it does not incorporate possible weakening at the welds and does not account for long term "creep" of the polymer (an ongoing stretching of the material) in response to stress, which is the primary strength consideration for any long life polymer application.

Previous tests performed in an investigation of possible absorption chiller applications ${ }^{9}$ showed that welded PFA tubes could withstand internal stress of up to 2180 psi (in the polymer) at $70^{\circ} \mathrm{F}$ and underwent creep of $1.5 \%$ in the first year under an internal stress of $810 \mathrm{psi}$ at $220^{\circ} \mathrm{F}$. Creep slows logarithmically with aging, so the next $1.5 \%$ should take approximately ten years. Since creep also slows dramatically with decreasing temperature, a design point internal stress of $1000 \mathrm{psi}$ will be quite conservative at $32^{\circ} \mathrm{F}$. Creep tests should be carried out at these temperatures before designs are made final.

Figure 4-1 shows the relationship between internal stress in the polymer, $S$, and the differential pressure between the inside and the outside of the tube, P. The diameter of the tube is $d$, the thickness of the material is $t$ and we are looking at a crosssection of a length $\ell$ of tube. The top half of the tube is in equilibrium between the upward force $\mathrm{F}=\mathrm{Pd} \ell$ due to the differential pressure and the downward force $F^{\prime}=2(\mathrm{St} \ell)$ due to the stress where the lower half of the tube is pulling on the upper half. Since $\mathrm{F}=\mathrm{F}^{\prime}, \mathrm{Pd} \ell=2 \mathrm{St} \ell$ and to withstand creep, the tubes should be subjected only to a differential pressure of $P<2 t S / d$. Taking " $t$ " as 0.003 inches (as in our experiments) and " $S$ " as $1000 \mathrm{psi}$, we find that the differential pressure should be constrained to $P<6.00 / \mathrm{d}$ psi for $\mathrm{d}$ in inches.

\subsection{Preliminary Design for R-134a}

R-134a would appear to be a more desirable choice for refrigerant than R-C318, since it is already in wide use in automotive air conditioning and is expected to gain more and more market share as chlorine-based compounds are phased out. However, for a polymer-based design, it presents significant design challenges. We will see in Chapter 5 that a reasonable maximum working temperature for the R-134 in the tubes will be $40^{\circ} \mathrm{F}$ (when the system is operating in cooling mode), and the data of Section 3 indicates that the corresponding pressure in the evaporating refrigerant is 50 psia. This pressure must be contained in accord with two distinct criteria: the design criteria that "creep" should be minimal and the ASME code 
requirement that these tubes be treated as a pressure vessel and be capable of withstanding seven times the design differential pressure. We deal with these two criteria in turn.

For design purposes, we will allow a steady differential pressure of $14.7 \mathrm{psi}$, for which the creep limitations derived just above imply a tube diameter of 0.404 inches, slightly smaller than the 0.45 inches used in the experimental ice maker tested in earlier experiments ${ }^{1}$. To ensure differential pressures less than $14.7 \mathrm{psi}$, the volume in which the pads reside, including the ice water and storage tank beneath them, must be pressurized to at least $50-14.7=35$ psia, or 21 psig.

The ASME code requirements can be met on the basis of tensile strength rather than creep criteria. We take the tensile strength of PFA teflon from earlier tests ${ }^{20}$ as 2180 psi. Using the formula from the previous paragraph divided by seven, we find the maximum differential pressure across the tube consistent with the ASME requirement to be $4.6 \mathrm{psi}$. Consequently, to keep the differential pressures within code limits, the ice water in the storage tank must be pressurized to $45 \mathrm{psia}$, or $31 \mathrm{psig}$ (a more stringent requirement than that derived in the previous paragraph).

This design, with the entire ice tank pressurized to about two atmospheres, will not cost anything energetically, since pumping is needed to push the cold water or slush ice around the building distribution system anyway; we are simply putting the pump before the tank rather than after it. Further, the tank offers protection to the local environment against pad breakage and refrigerant release. We are not sure whether the pressure vessel code would require the tank to be constructed to the "7X" standard as well, but will assume below that it does. If the standard can be relaxed, either for the pads or for the tank, the costs of the system can be lowered.

The resulting assembly is shown in Figure 4-2. The tanks are capped cylindrical steel with substantial insulation. Appendix B details and further illustrates the sizing calculations based on the $16,300 \mathrm{ft}^{3}$ storage volume ${ }^{2}$; sizing is more practical with four equal tanks, and this offers advantages in operational security and maintenance flexibility as well. The pads occupy a rectangular volume at the top of each tank, and can be extracted for maintenance, along with refrigerant piping and supports, from one end.

Appendix B also details the wall thickness calculations, based on a value for the tensile strength of ASTM A284 steel, 55,000 $\mathrm{psi}^{21}$, which when coupled with a calculation similar to that performed just above for the tubes in each pad indicates that 0.33 inch thick steel is adequate for the tanks, and that they will require $90,500 \mathrm{lbs}$ of steel, plus supports, ribbing, flanges and so forth. It might be possible to use less material through clever ribbing, but we will use these values to be conservative.

The total ice-making area and the number of pads required will depend on the speed with which ice forms on the surfaces, and this will depend on the thermodynamic calculations to be developed in Section 5, below. As shown in Figure 4-2 and Appendix B, the pads must fit into 


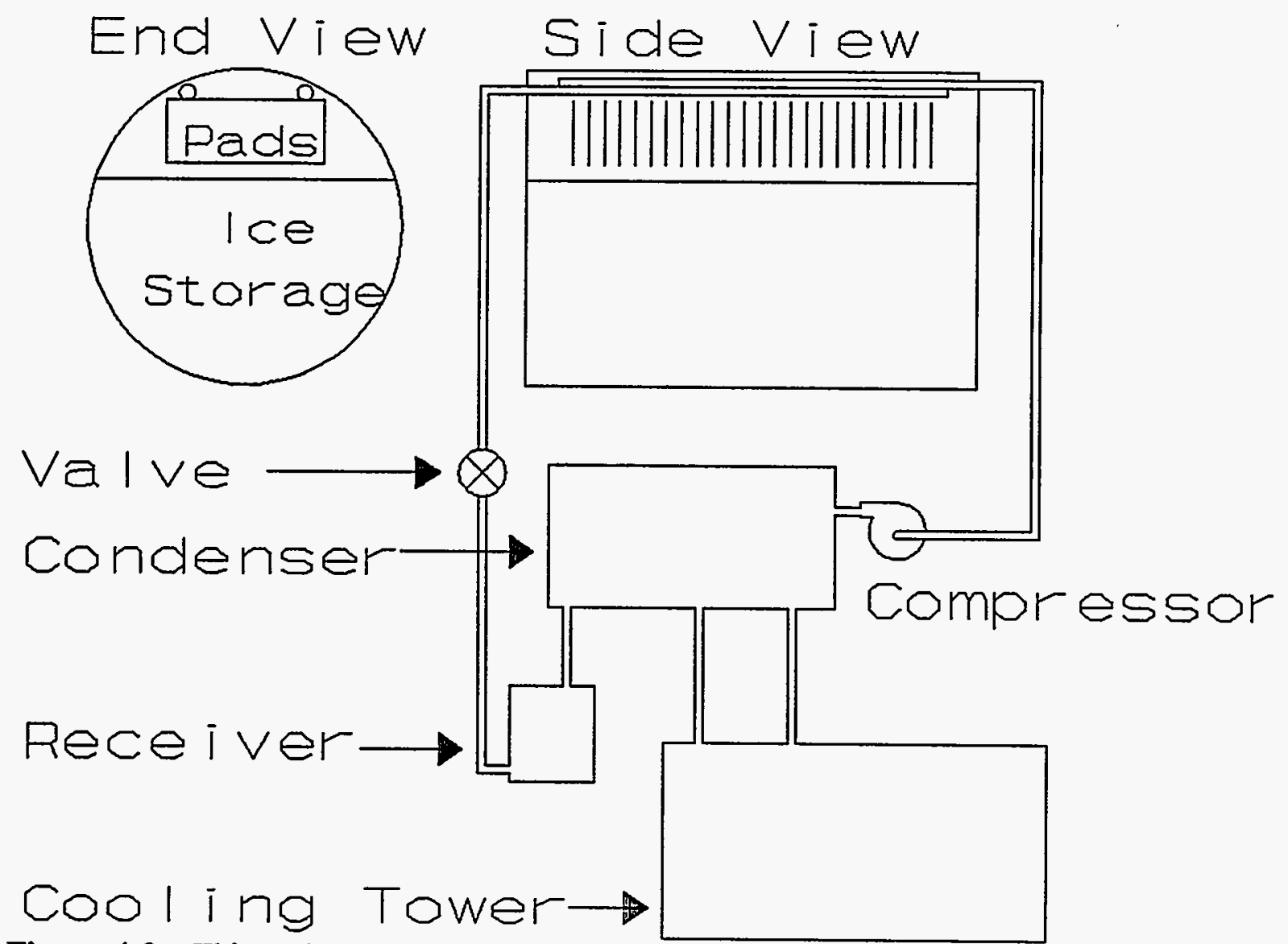

Figure 4-2: Thin Polymer Ice Maker and Tank: Conceptual Design.

a rectangular space two feet high, seven feet wide and extending the length of the tank. Leaving space for individual support structures, the active height of a pad will be 18 inches, consisting of 34 tubes each 0.404 inches in diameter. Appendix C details and illustrates various pad dimensions and quantities as outlined here and developed below.

For optimal heat transfer, each evaporator tube should remain flooded over its entire length. This can be assured by inserting a narrow (1/16-inch ID) metal tube equipped with regularly spaced orifices down the center of each polymer evaporator tube and injecting the fluid through it, so that the fluid sprays out radially within the evaporator tube. In Appendix D we calculate pressure drops in a system of distribution tubing between the pads and in pads composed of "Headers" at each end and "Tubes" on which the ice actually forms. The calculation is presented for the more demanding water chilling mode of operation; all pressures are lower when ice is being made. The "System Totals" show that pressure drops are acceptable if the tubes are three feet long, and we will assume this is the case in subsequent modelling. Power consumption is also calculated in Appendix D for use in Chapter 6. 
We believe the design outlined here presents a conservative basis for calculating performance and estimating system costs. Some trade-offs should be kept in mind: although operating in cooling mode offers substantial operating savings, it is forcing us to design a system based on the vapor pressure of R-134a at $40^{\circ} \mathrm{F}$. If the system were restricted to operating solely to make ice, the maximum R-134a temperature would be about $28^{\circ} \mathrm{F}$, the pressure under 40 psia and the required steel reduced to 59,000 pounds. This option should be examined if real designs are to be developed along the lines sketched here.

\subsection{Preliminary Design for R-C318}

An even more optimal solution would result from the use of C-318, since its lower operating pressures would allow the use of less expensive containment. The analysis of Section 4.2 is readily adapted to this case. With respect to our long-term design goal of containing creep, assuming the same geometry and material, we still need to keep the differential pressure across the tubes under $14.8 \mathrm{psi}$. However, this is now easy, since the analysis of Chapter 5 will show that during water chilling the pressure of the evaporating R-C 318 will be $145.6 \mathrm{kPa}$, equal to 21.2 psia or $6.5 \mathrm{psig}$, well below the 14.8 psig limit.

The requirements of the ASME pressure vessel code are again somewhat more exacting. For the same geometry and material, the maximum differential pressure is again $4.6 \mathrm{psi}$. Since this is less than the $6.5 \mathrm{psig}$ of the evaporating R-C318, the structure would have to be pressurized, but only at 1.9 psig. Following the approach of Section 4.2 and enclose the pads and ice water in steel pressure vessels, it could be constructed of 20-mil strip steel.

This would not be strong enough to retain the ice water, and for R-C318, our conceptual design will assume that the ice water storage is in insulated, rectangular concrete tanks, as is often done with commercial systems today, and as was assumed in our earlier study ${ }^{2}$. The modest pressurization would be achieved by installing a sealed semi-cylindrical steel cover which would house the pads and distribution piping. Except for these greatly reduced housing requirements, the system is identical to that developed for R-134a, and the cost estimates to be developed in Chapter 6 will reflect this. Appendix E shows that because more refrigerant must be pumped; the pressure losses and power consumption are higher than for R-134a. Although pipe sizing should be optimized before such a system is built, we have left all sizes the same as for R-134a; the resulting increase in pumping costs will be larger than the cost increase in an optimized system.

We have confidence in our system design and cost estimates, but the practicality of using $\mathrm{R}-\mathrm{C} 318$ is considerably less certain than was the case with R-134a. The properties of the pure chemical are well known, but we have not found a case where it has been used commercially. Its interactions with lubricants and seals are unknown, as is its long-term stability in a continuously cycling application. Its price in quantity at commercial purity is not clear either; that of highly purified laboratory material is prohibitive. However, the promise our systems analysis reveals indicates that investigation of these concerns would be a worthwhile endeavor. 


\section{SYSTEM MODELLING AND EXPECTED EFFICIENCY}

In this section we develop a thermodynamic model of the thin polymer ice maker suitable to estimate the overall efficiency of the system and to determine typical operating parameters and conditions. We apply this model to a system based on R-134a and to two systems based on RC318.

\subsection{Description of Model}

The model ' includes standard characterization of heat transfer in the thin polymer evaporator and in a water-cooled condenser, which is assumed connected to a wet cooling tower, as shown in Figure 5-1. The chilling cycle itself is represented by the ASHRAE "Actual Basic Vapor Compression Cycle"22, which includes the major irreversible losses associated with the vapor compression cycle. The model is constructed so that when the evaporator temperature changes as ice-making and water-cooling operation are compared, the compressor

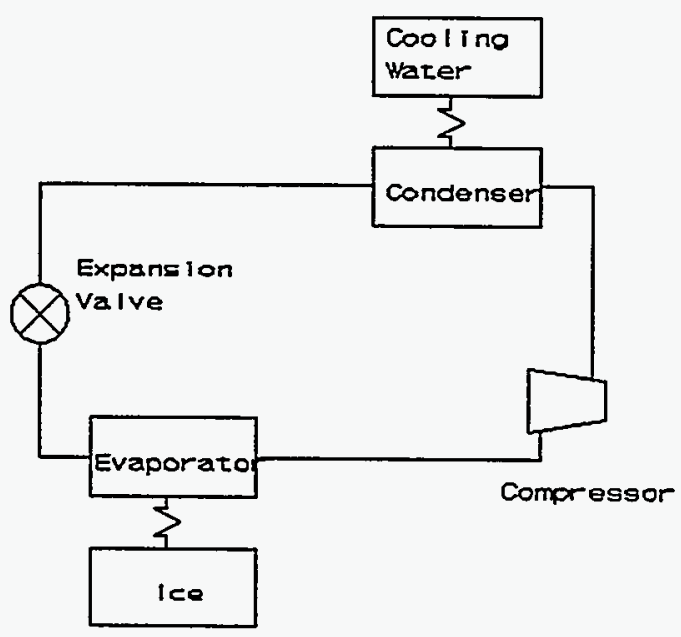

Figure 5-1: Ice Maker System Diagram. operates at a constant displacement (rather than constant mass flow or constant evaporator capacity), as a standard, single-speed compressor would.

The model is displayed for the case where R-134a is used in ice making in Figure 5-3, in chilling $45^{\circ} \mathrm{F}$ water in Figure 5-4 and in similar calculations for R-C318 in following figures. In these figures, the numbers in gray boxes are determined externally and typed in, while those in white areas are calculated by algorithms within the spreadsheet. To the right in each figure, temperature-entropy and pressure-enthalpy diagrams are sketched in. The (approximately) reversible portions are shown as solid lines, the irreversible parts as heavy dotted lines and the approximate position of the refrigerant's saturation curves is indicated by light dashed lines.

The evaporator is described in the upper left-hand box of the figures. For ice making, the key temperature is that at the ice-water interface, where freezing is actually occurring. As shown in Figure 5-2, this is the source of latent heat of fusion which must be transported through the ice and the polymer wall to the refrigerant vapor. If the water is above the freezing point, it must also be cooled down, but a simple calculation shows that for water a few degrees above freezing, this will produce heat amounting to only a few per cent of the latent heat of fusion ${ }^{23}$, which we ignore in these calculations. 
The ice building process takes place in intervals such that the maximum thickness is about one millimeter ( 0.04 in.), so on average the thickness is one-half millimeter which combines with the thermal conductivity of ice to give a heat transfer coefficient of $3.2 \mathrm{~kW} / \mathrm{m}^{2}{ }^{\circ} \mathrm{C}$ (all internal calculations in the model are in SI units; results are given in both SI and conventional American units.) For 3-mil (75 micron) PFA film, the thermal conductivity ${ }^{8}$ gives a heat transfer coefficient of $0.99 \mathrm{~kW} / \mathrm{m}^{2}-{ }^{\circ} \mathrm{C}$.

Finally, ASHRAE gives an estimate

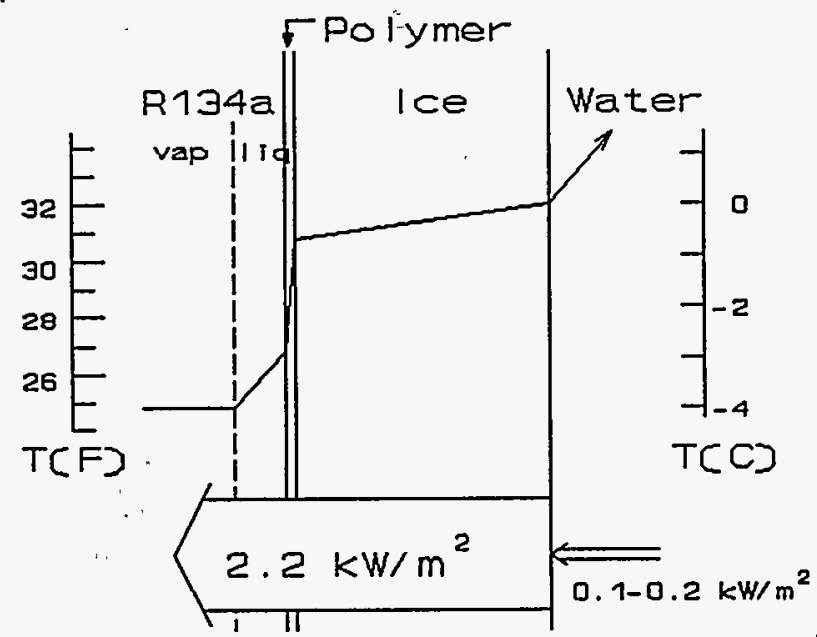

Figure 5-2: Heat Flow in Ice Building. of $2.0 \mathrm{~kW} / \mathrm{m}^{2}-{ }^{\circ} \mathrm{C}$ for R-12 (Ref. 3, p. 4.5 , Fig. 8) as the refrigerant boils in the evaporator tube. R-134a should show similar heat transfer performance ${ }^{24}$; and experimental data for R-134a found after our calculations were completed $^{25}$ indicates that this is a reasonable and perhaps conservative assumption. The flow configuration used in these recent experiments differed from ours, and without experimental data for the polymer tubes in our arrangement it is doubtful that more detailed predictions would yield greater confidence. Also, the relatively high thermal resistance of the polymer wall insures that variations of $1 \mathrm{~kW} / \mathrm{m}^{2}{ }^{\circ} \mathrm{C}$ up or down in the boiling heat transfer coefficient of the refrigerant result in only a $10-20 \%$ variation in the overall coefficient. Consequently, we simply use this R-12 estimate for R-134a. We have found no phase-change heat transfer data for RC318, and use the R-12 estimate in those calculations as well.

Pressure loss down the evaporator tubes is ignored in the cycle calculations (although included in Appendices D and E). The total heat exchange area of $185 \mathrm{~m}^{2}$ is found by an iterative process (described below). This area is multiplied by the inverse of the sum of the inverses of these three series-connected elements to give the overall evaporator heat transfer coefficient of $101 \mathrm{~kW} /{ }^{\circ} \mathrm{C}$. The evaporator load of $407 \mathrm{~kW}$ (calculated below) is then used to find the consistent refrigerant temperature of $28^{\circ} \mathrm{F}\left(-2.2^{\circ} \mathrm{C}\right)$, which is used in the cycle calculations below.

For the water chiller analysis of Figure 5-4, the evaporator is analyzed in the same way except that the heat source is $45^{\circ} \mathrm{F} \cdot\left(7.2^{\circ} \mathrm{C}\right)$ water, and the corresponding heat transfer coefficient for cold water flowing over the outside of horizontal tubes is $0.9 \mathrm{~kW} / \mathrm{m}^{2}-{ }^{\circ} \mathrm{C}^{26}$. The results are discussed below.

The condenser is assumed to have refrigerant condensing on tubes containing water from a cooling tower, taken to have a temperature of $95^{\circ} \mathrm{F}\left(35^{\circ} \mathrm{C}\right)$ over the entire length of the condenser, a simpler but more conservative assumption than the standard of $85^{\circ} \mathrm{F}$ entering and $95^{\circ} \mathrm{F}$ leaving water temperatures. The heat transfer coefficient from this in-tube water to the 

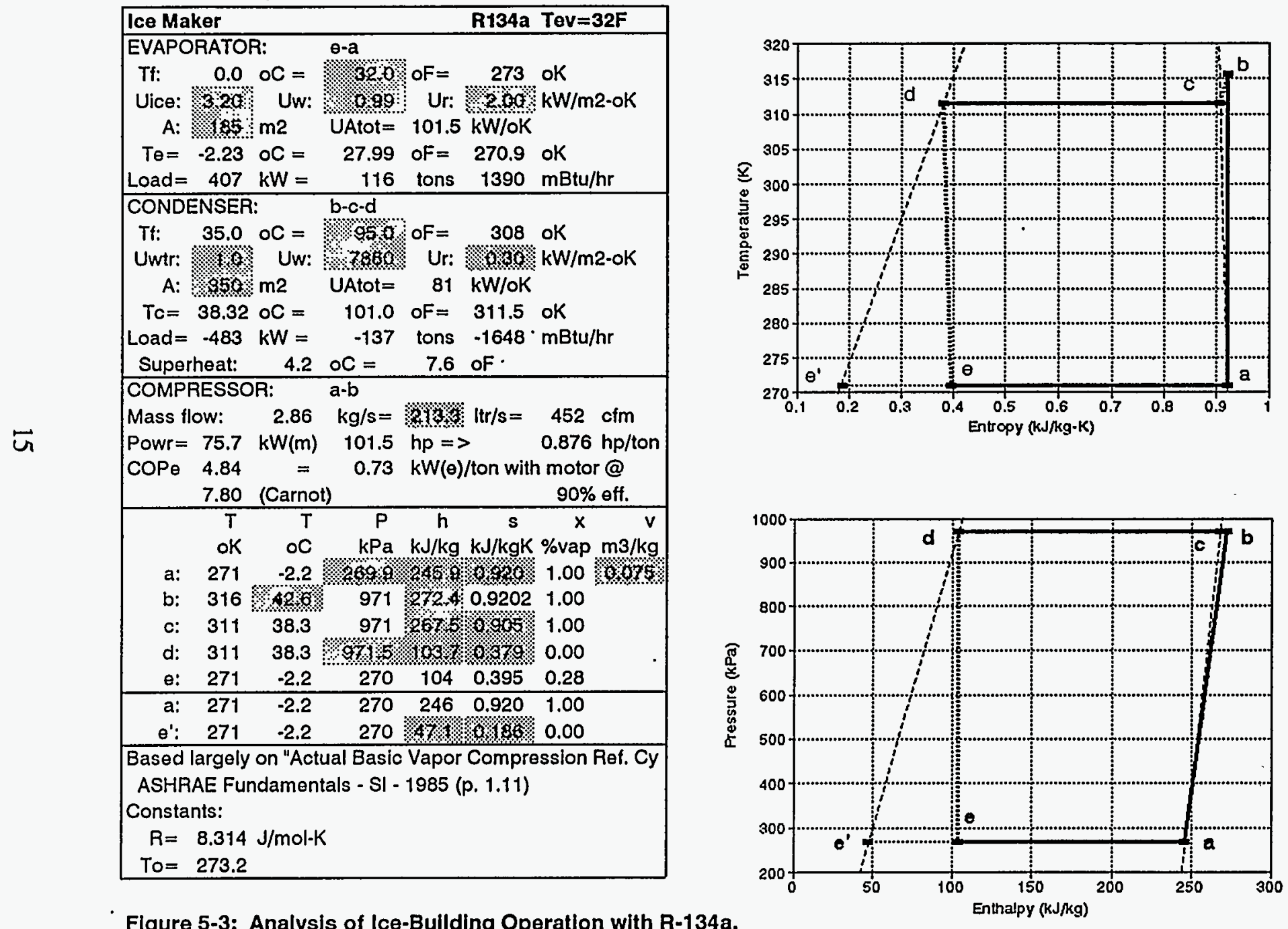

Figure 5-3: Analysis of Ice-Building Operation with R-134a. 


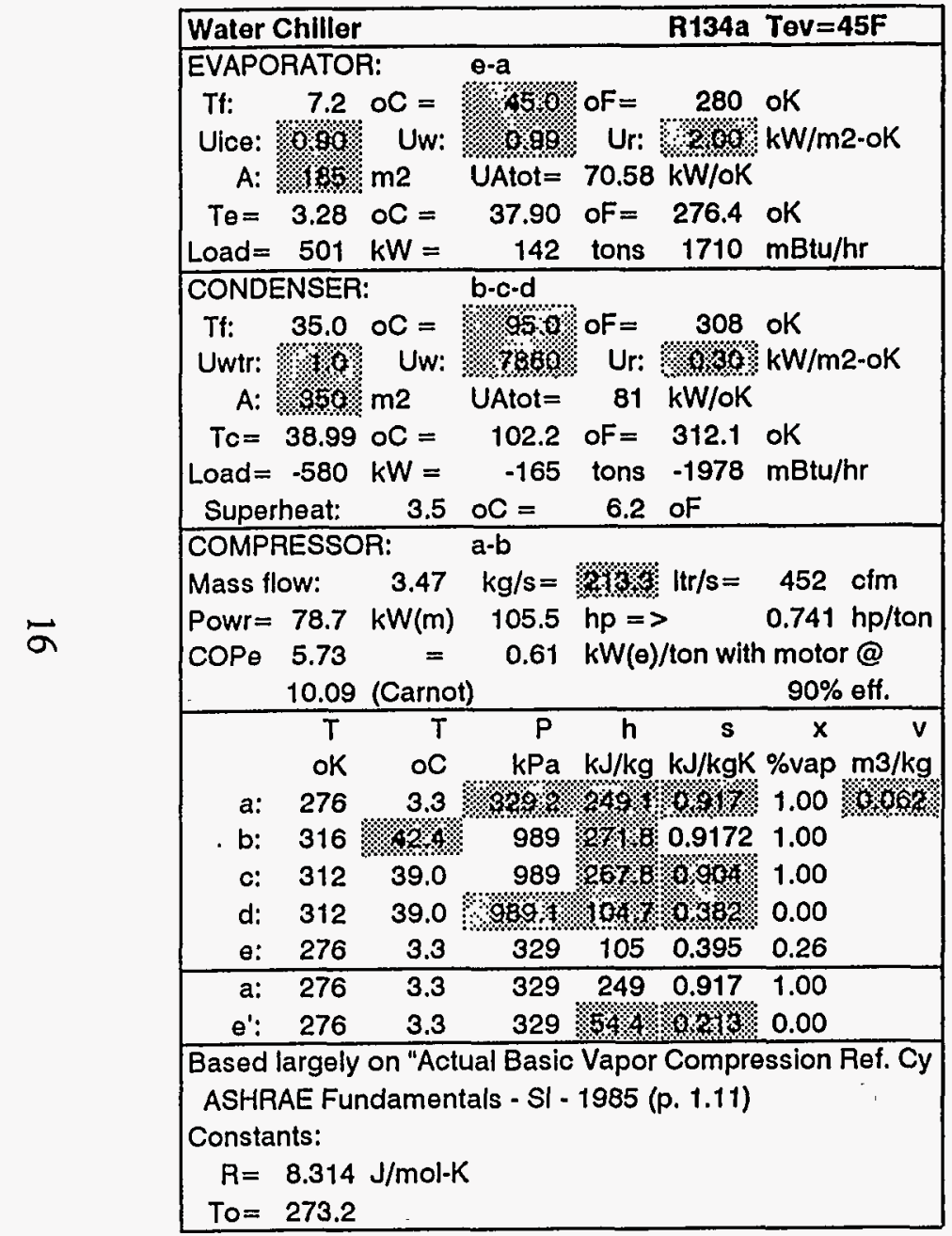
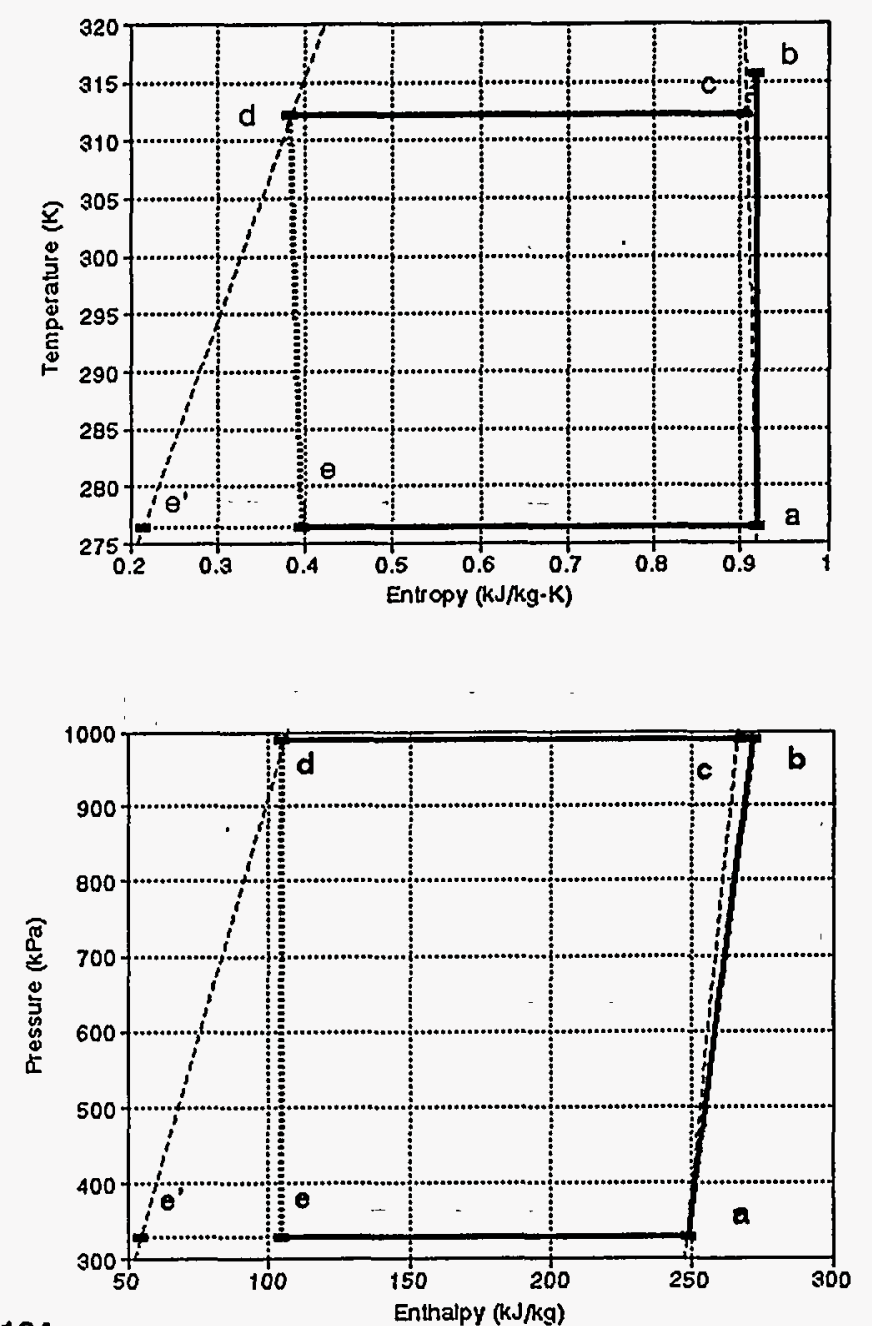

Figure 5-4: Analysis of Water-Chilling Operation with R-134a. 
metal of the tubes is $1.0 \mathrm{~kW} / \mathrm{m}^{2}-{ }^{\circ} \mathrm{C}^{27}$, the metal is an essentially infinite $7860 \mathrm{~kW} / \mathrm{m}^{2}-{ }^{\circ} \mathrm{C}$ and the film of condensing, nearly static refrigerant has a limiting heat transfer coefficient of 0.3 $\mathrm{kW} / \mathrm{m}^{2}-{ }^{\circ} \mathrm{C}^{28}$. As before, these are combined with an exogenously-derived heat exchange area of $350 \mathrm{~m}^{2}$ to give an over-all condenser heat transfer coefficient of $81 \mathrm{~kW} /{ }^{\circ} \mathrm{C}$. The condenser load, calculated below as $483 \mathrm{~kW}$, then determines the delta- $\mathrm{T}$ and the refrigerant temperature of $101^{\circ} \mathrm{F}\left(38.3^{\circ} \mathrm{C}\right)$. The superheat, calculated below, is also reported in this box.

The compressor model is governed by the volumetric displacement, entered by the user. The vapor density (calculated below) then gives the mass flow, and the pressure difference between points "a" (compressor input port) and "b" (output port) multiplied by the volumetric displacement gives the mechanical power requirement reported here. Overall motor and compressor efficiency, taken as $90 \%$, results in the indicated electric power requirements and the COP, which is compared to the efficiency of a Carnot refrigerator operating between the temperatures of the ice (or chilled water) and the $95^{\circ} \mathrm{F}$ cooling water.

The next box displays temperature, pressure, enthalpy, entropy and vapor fraction at the five state points and vapor density at the compressor input. Points "a" and " $\mathrm{e}$ " in the evaporator have the same pressure and temperature, differing in vapor fraction. (We have assumed a perfectly sized evaporator, so that the vapor fraction becomes unity just as the vapor enters the compressor.)

Points "b", "c" and "d" in the condenser are all at the same pressure, and "c" and "d" are at the same (liquid-vapor equilibrium) temperature. Similarly to our treatment of the evaporator, we assume the condenser is sized so as to just avoid sub-cooling the liquid after it has all condensed. The temperature at " $b$ " is determined by demanding both $\mathrm{P}_{b}=\mathrm{P}_{c}$ and $\mathrm{S}_{\mathrm{b}}=\mathrm{S}_{\mathrm{a}}$ as a result of isentropic compression.

The other enthalpies and entropies are determined using the formulas for R-134a discussed in Section 3 above. The enthalpy at the hypothetical point " $\mathrm{e}^{\prime \prime}$ (which is at the evaporator pressure and equilibrium temperature, but is $100 \%$ liquid) is combined with the enthalpies at "e" and "a" to determine the vapor fraction at $\mathrm{e}$, although it is not required for the cycle analysis.

Three exogenously determined parameters define the mechanical system: the heat exchange areas of the evaporator and condenser and the displacement of the compressor. Also, two temperatures, that of the condenser cooling water and of the ice or chilled water in contact with the evaporator, define the operating conditions. With these five quantities specified, it is necessary to iterate the model two or three times to find a set of internally consistent temperatures and pressures, since changing the heat flow through the condenser and evaporator will change the temperature drop across them. Repeating these iterations for each configuration, variation of the compressor displacement and heat exchange areas allows determination of a system having the desired capacity and reasonable temperature drops across the condenser and evaporator. 
The model was first validated by using R-22 data and duplicating ASHRAE performance tables ${ }^{29}$ with respect to evaporator and condenser temperatures; in these cases the heat exchange areas were set very large, since ASHRAE dealt only with thermodynamic calculations. Then the heat exchange areas of the evaporator and condenser were decreased to physically reasonable values, and capacity and COP both dropped, as expected. In a detailed design study, optimal sizes would be found considering the trade-off between the cost of more heat exchanger and the lowered operating costs that more heat exchange area makes possible. For our purposes, such a detailed study would be premature, and we simply chose heat exchange areas and a compressor displacement that gave modest temperature drops across the evaporator and condenser.

Clearly there are ways this model could be over-estimating performance. We have mentioned ignoring pressure drops down the condenser and evaporator tubes and assuming perfect sizing for these components, so that vapor fractions always turn out exactly as they should. Also, our heat transfer coefficients are theoretical or rule-of-thumb estimates, a situation which can only be convincingly improved by building a prototype machine. However, there are also steps which can be taken in large machinery to improve efficiency, such as economizers, inter-cooled two stage compression and variable speed compressors, and we have not incorporated any of these gains into the model. We are confident that the level of accuracy employed here is appropriate for a demonstration of viability.

\subsection{System Modelling with R-134a}

Then the refrigerant data was then switched from R-22 to R-134a, without otherwise altering the machine. The result was a machine with lower capacity and higher COP, and with noticeably less superheat with R-134a than with R-12.

We then re-sized the components to model a machine with 116 tons of cooling power. Again, we did not truly optimize, but selected an evaporator temperature drop of $4^{\circ} \mathrm{F}\left(2.2^{\circ} \mathrm{C}\right)$ and a condenser drop of $6^{\circ} \mathrm{F}\left(3.4^{\circ} \mathrm{C}\right)$. The result is the system characterized in Figure 5-3. It has an over-all COP of 4.8 , corresponding to an efficiency of $0.81 \mathrm{~kW}_{\mathrm{e}} /$ ton. With an evaporator area of $185 \mathrm{~m}^{2}\left(1990 \mathrm{ft}^{2}\right)$ it meets our design point cooling load of 116 tons $\left(407 \mathrm{~kW}_{\mathrm{th}}\right)$. This is less than one half the pad area required for our earlier design ${ }^{2}$, which will result in substantial cost savings, so we do not attempt to lower pad area further by allowing larger temperature drops between ice and refrigerant.

Figure 5-4 then shows that this same system can provide 142 tons $\left(501 \mathrm{~kW}_{\mathrm{th}}\right)$ of cooling to $45^{\circ} \mathrm{F}$ water at a COP of $5.7\left(0.68 \mathrm{~kW}_{\mathrm{e}} /\right.$ ton $)$. Operating in this mode when water that has been warmed in the building's cooling system is available offers substantial savings. The efficiency figures derived for both ice-building and water chilling are used in Chapter 6 to estimate annual operating costs. 


\subsection{System Modelling with R-C318}

Operating the model shown in Figure 5-1 with the refrigerant characteristics for R-C318 described in Chapter 3, we found that the machine described in Figure 5-1 and Figure 5-5 would produce ice with a design point capacity of 116 tons. Because the heat transfer properties are the same, the heat exchanger sizes are unchanged, but R-C318 requires a compressor with more than twice the volumetric capacity of that in the R-134a system. The system operates with an acceptable COP of 4.4, corresponding to $0.89 \mathrm{~kW}_{\mathrm{e}}$ per ton. Water chilling operation is described in Figure 5-6. Again, the COP is about $9 \%$ lower than for the comparable R-134a machine, but otherwise operation is comparable.

For both cases, the temperature-entropy diagrams reveal the unusual behavior predicted in Chapter 3: because the vapor equilibrium curve bends out to the right as entropy increases, the refrigerant will partially condense during compression. Calculating this effect required some straightforward re-arrangement of the spreadsheet, which now finds the vapor fraction at " $b$ " (the compressor output/condenser input) as well as at " $\mathrm{e}$. About $12 \%$ of the vapor is condensed during the compression stroke. This is probably not analogous to the "slugging" that occurs when un-evaporated liquid is pulled into the compressor, since the condensation will take place throughout the well-mixed vapor, resulting in a heavy mist which should not cause undue stress on the compressor.

However, this situation is one that is unfamiliar and therefore troubling, and it also results from a cycle that is less than optimal. If the vapor coming from the evaporator were suitably superheated before compression, it would enter the condenser with a vapor fraction of $100 \%$, avoiding the uncertainties of "misting" in the compressor and the attendant inefficiencies. This can be achieved by adding a heat exchanger between fluid exiting the condenser and that which is entering the compressor, as shown in Figure 5-7.

Operation of this system is shown in Figure 5-8 and Figure 5-9. The vapor

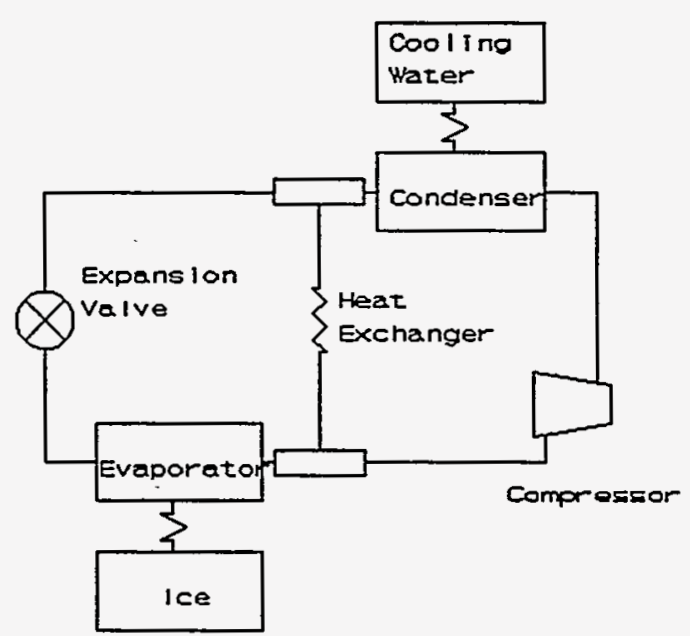

Figure 5-7: Ice Maker Superheated System Diagram. exiting the evaporator at "a" is superheated until its entropy at " $b$ " equals that at "c", the entrance to the condenser. Knowing the entropy and temperature allows us to determine the temperature and enthalpy at "b" from the refrigerant properties, and this determines the quantity of heat needed to produce this superheat. The hot liquid exiting the condenser at " $\mathrm{d}$ " is sub-cooled until it enters the expansion valve at " $\mathrm{d}$ '", with its enthalpy, entropy and temperature all reduced by the removal of the heat. 


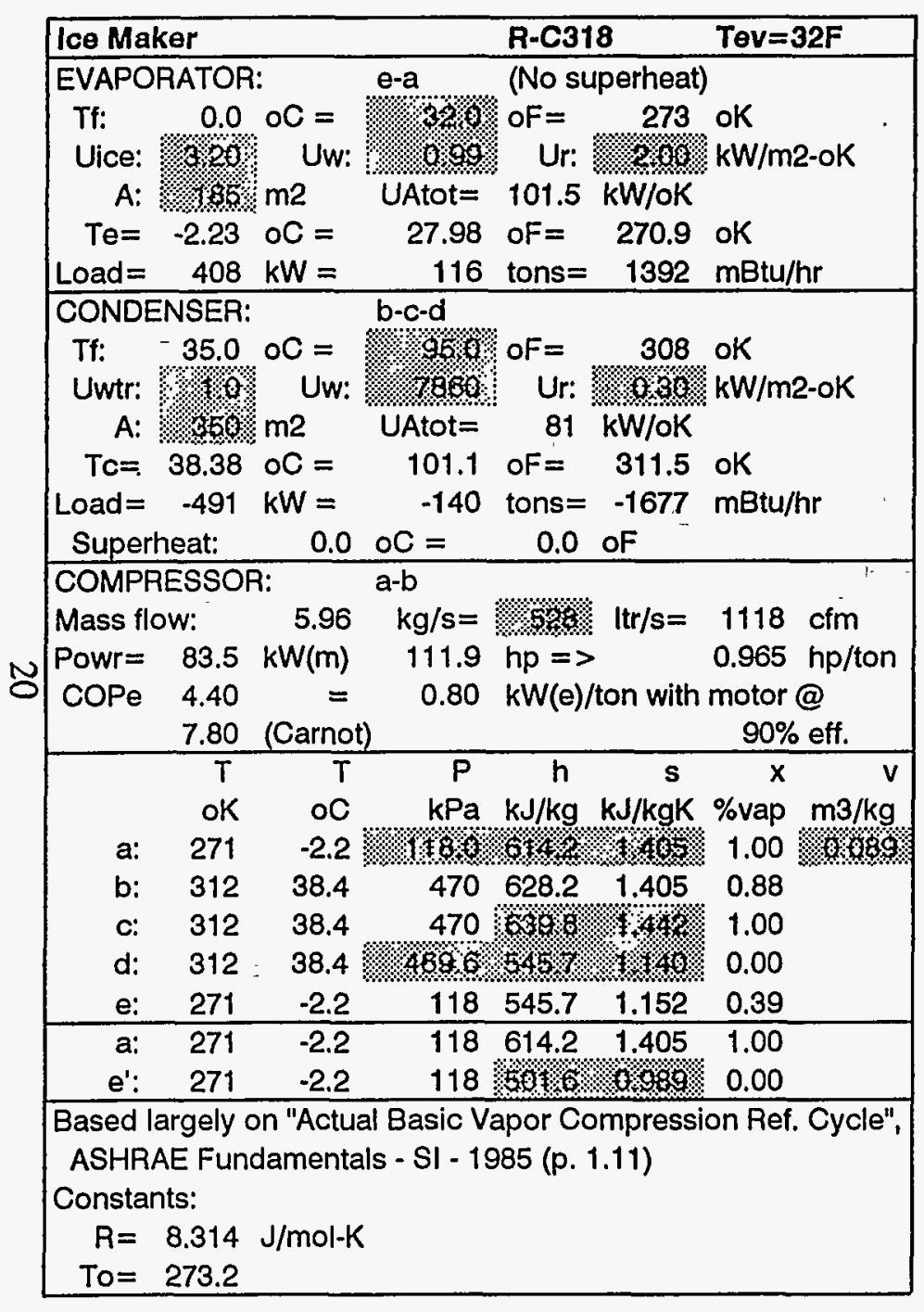

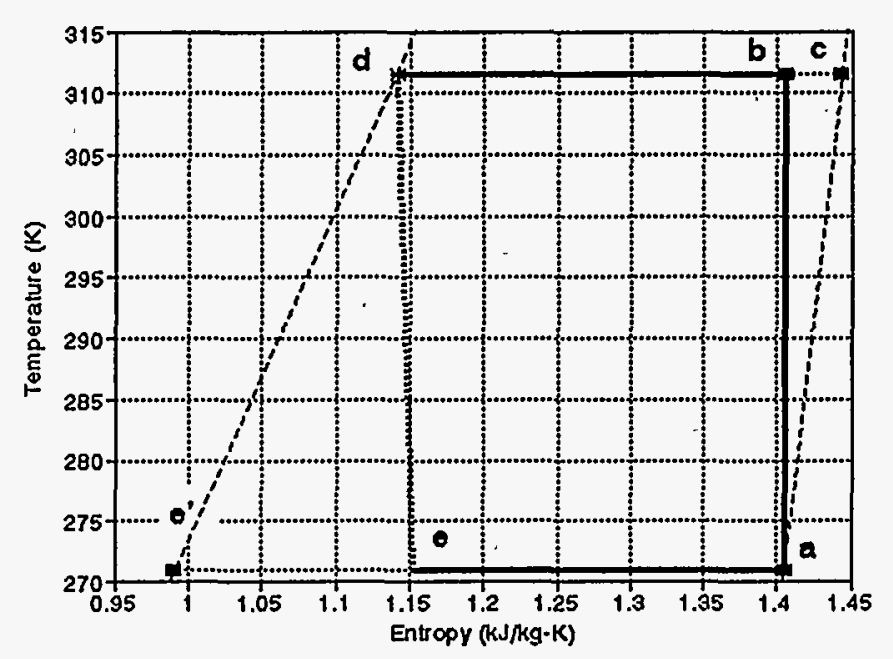

Figure 5-5: Analysis of Ice-Building Operation with C318.

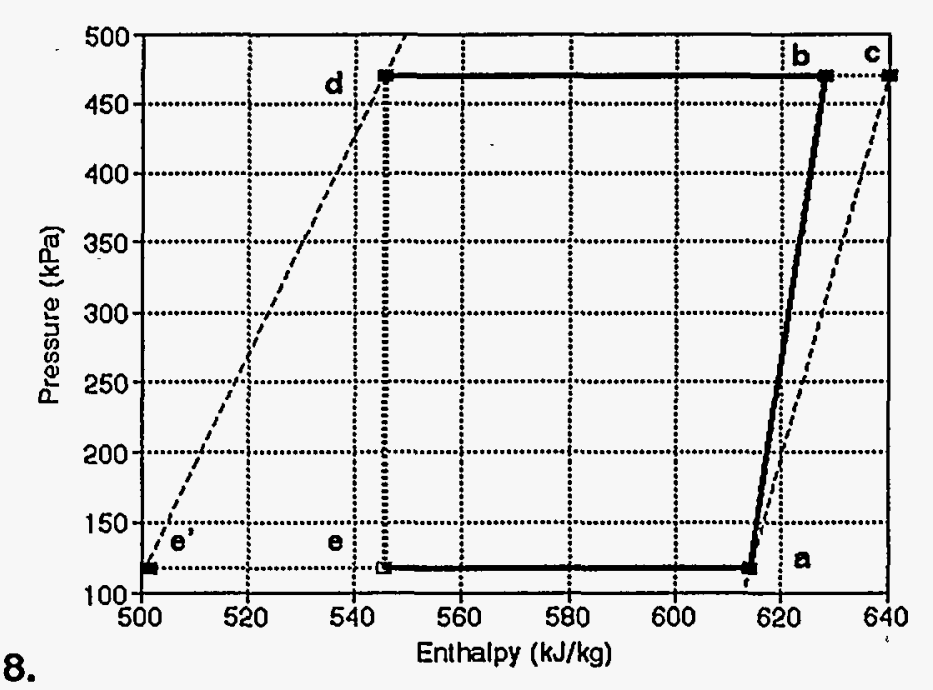




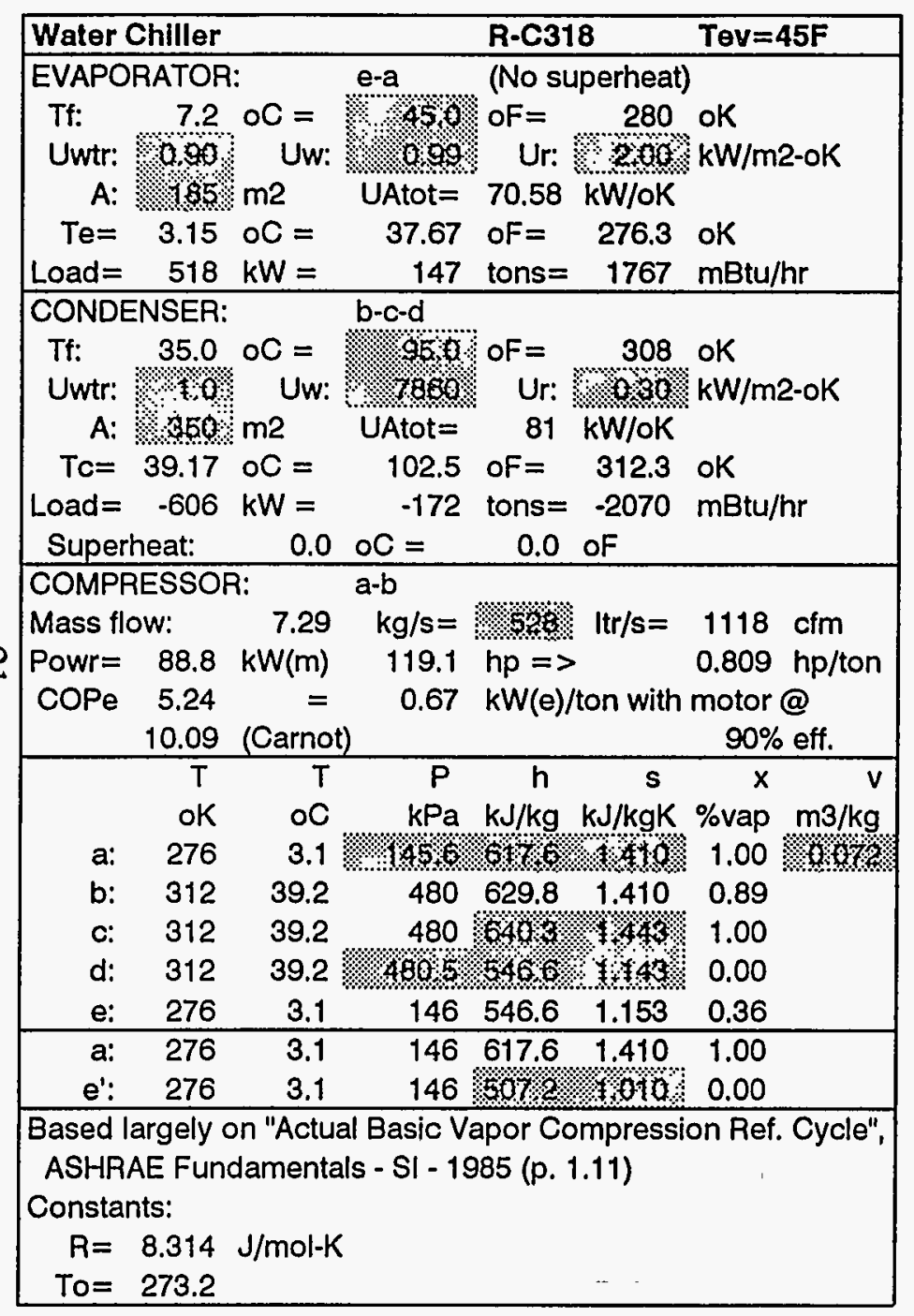
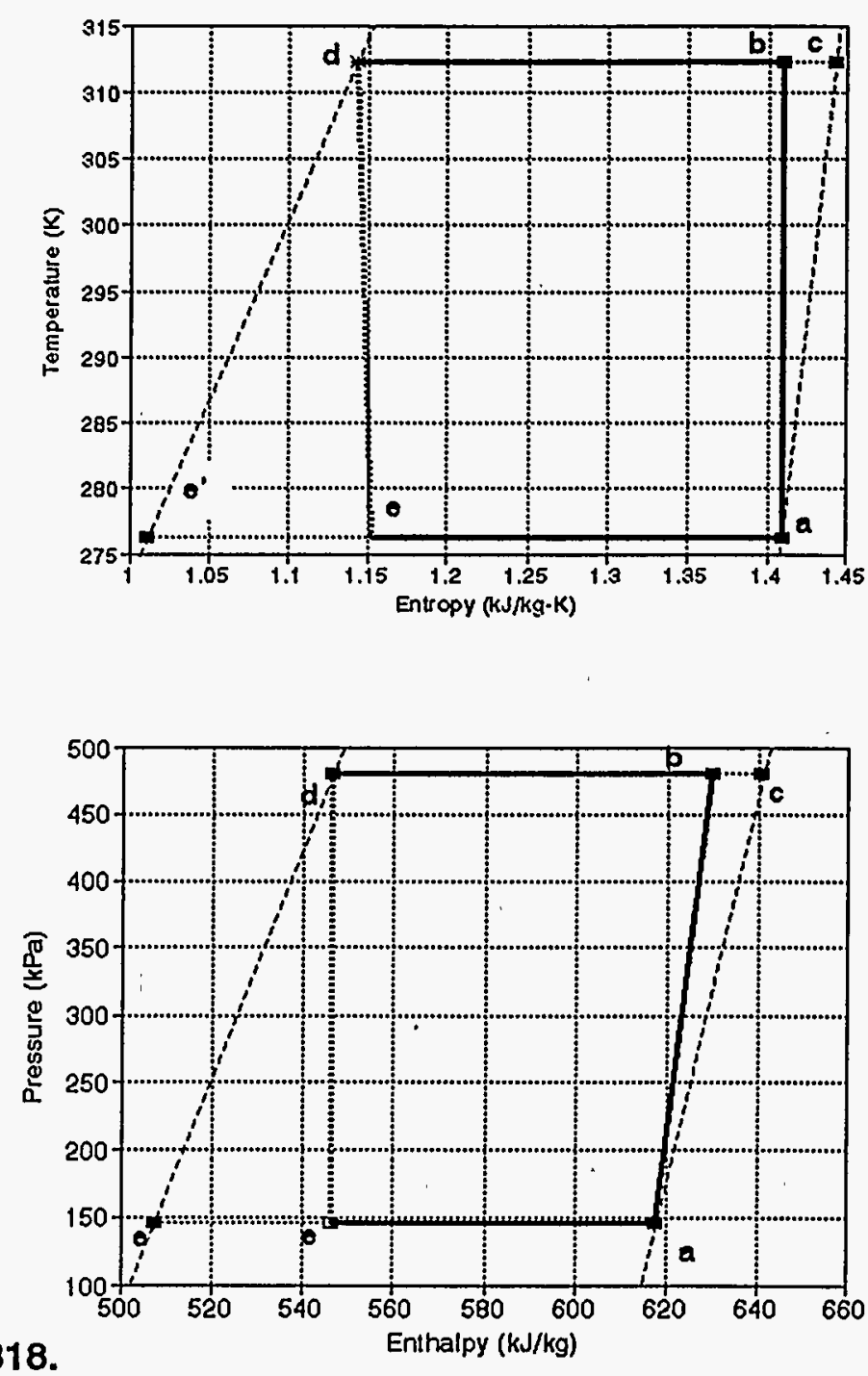

Figure 5-6: Analysis of Water-Chilling Operation with C318. 


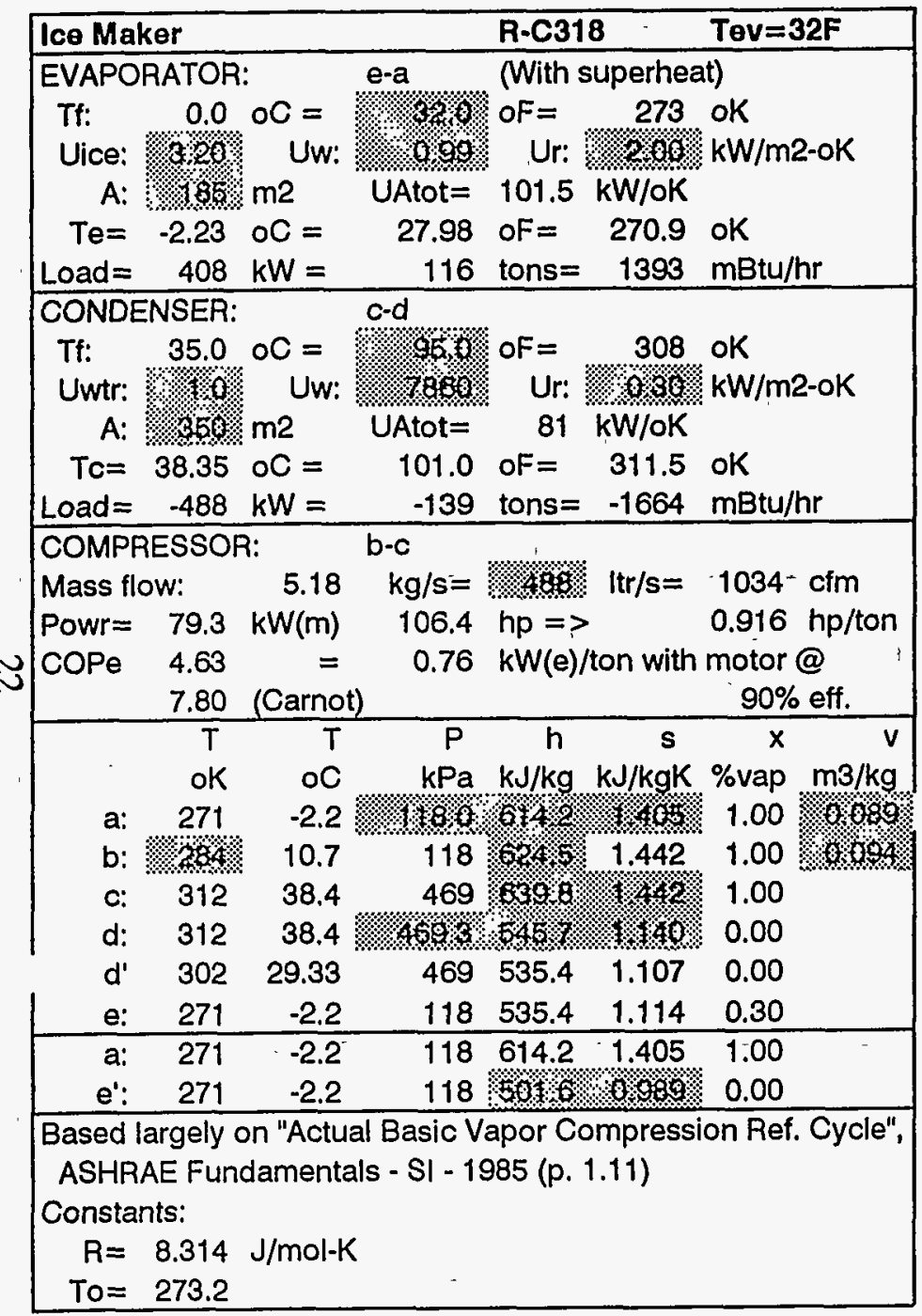
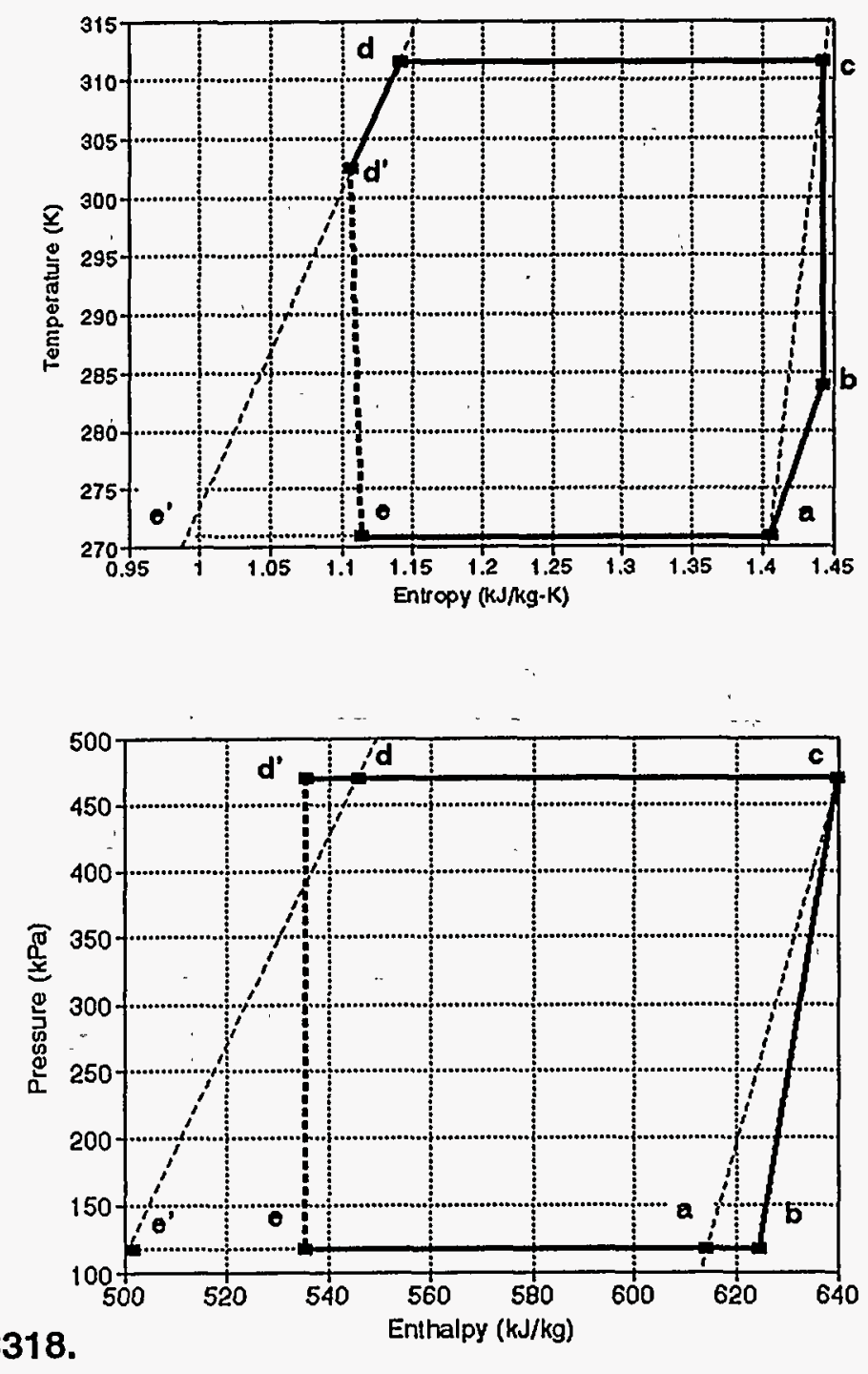

Figure 5-8: Analysis of Ice-Building with Superheated C318. 


\begin{tabular}{|c|c|c|c|}
\hline \multicolumn{2}{|l|}{ Water Chiller } & R-C318 & Tov $=45 \mathrm{~F}$ \\
\hline EVAPORATOR: & $e-a$ & \multicolumn{2}{|c|}{ (With superheat) } \\
\hline Tf: $\quad 7.2 \circ \mathrm{OC}=$ & $\%: 490$ & $O F=280$ & oK \\
\hline Uice: 83,0 & 100 & Ur: 3 200 & $\mathrm{~kW} / \mathrm{m} 2-\mathrm{oK}$ \\
\hline$A: 1015$ m2 & UAtot $=$ & $101.5 \mathrm{~kW} / \mathrm{oK}$ & \\
\hline 4.28 oC $=$ & 39.70 & $o F=\quad 277.4$ & oK \\
\hline Load $=538 \mathrm{~kW}=$ & 153 & tons $=$ & $\mathrm{mBtu} / \mathrm{hr}$ \\
\hline CONDENSER: & \multicolumn{3}{|l|}{$c-d$} \\
\hline Tf: $\quad 35.0$ oC $=$ & 201 & oF $=$ & oK \\
\hline 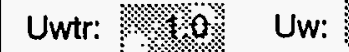 & 7860 & Ur: $/ 9,9$ & $\mathrm{~kW} / \mathrm{m} 2-\mathrm{oK}$ \\
\hline A: 56 m2 & UAtot $=$ & $81 \mathrm{~kW} / \mathrm{ok}$ & \\
\hline $\mathrm{Tc}=39.28 \mathrm{oC}=$ & 102.7 & $o F=\quad 312.4$ & oK \\
\hline Load $=-623 \mathrm{~kW}=$ & -177 & tons $=$ & $\mathrm{mBtu} / \mathrm{hr}$ \\
\hline \multicolumn{4}{|c|}{ COMPRESSOR: $\quad \mathrm{b}-\mathrm{c}$} \\
\hline Mass flow: & $\mathrm{kg} / \mathrm{s}=$ & \% $\%$ ofo & $1034 \mathrm{cfm}$ \\
\hline Powr $=85.0$ & 114.0 & $h p=>$ & $0.745 \mathrm{hp} /$ ton \\
\hline $\mathrm{COPe}$ & 0.62 & \multirow{2}{*}{\multicolumn{2}{|c|}{$\begin{array}{r}k W(e) / \text { ton with motor @ } \\
90 \% \text { eff. }\end{array}$}} \\
\hline (Carnot) & & & \\
\hline$T$ & $P$ & $h \quad s$ & $\begin{array}{ll}\mathrm{x} & \mathrm{V}\end{array}$ \\
\hline oC & $\mathrm{kPa}$ & $\mathrm{kJ} / \mathrm{kg} \mathrm{kJ} / \mathrm{kgK}$ & $\%$ vap $\mathrm{m} 3 / \mathrm{kg}$ \\
\hline 277 & \%1521 & $618 \%$ r. $1 \times 1 \%$ & $1.00 \geqslant 0.000$ \\
\hline b: $/ \alpha_{0}$ & 152 & 62781.443 & 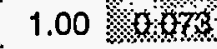 \\
\hline c: $\quad 312$ & 482 & $840 \%$. 1.1449 & 1.00 \\
\hline 39.3 & 1480 & 6468 - 444 & 0.00 \\
\hline 31.20 & 482 & $537.5 \quad 1.114$ & 0.00 \\
\hline 277 & 152 & 537.5 & 0.26 \\
\hline 277 & 152 & $618.4 \quad 1.411$ & 1.00 \\
\hline $\begin{array}{lll}e^{\prime}: & 277 & 4.3 \\
\end{array}$ & 152 & $3085.4 \times 44$ & 0.00 \\
\hline \multirow{2}{*}{\multicolumn{4}{|c|}{$\begin{array}{l}\text { Based largely on "Actual Basic Vapor Compression Ref. Cycle", } \\
\text { ASHRAE Fundamentals - SI - } 1985 \text { (p. 1.11) } \\
\text { Constants: }\end{array}$}} \\
\hline & & & \\
\hline \multicolumn{4}{|l|}{$R=8.314 \mathrm{~J} / \mathrm{mol}-\mathrm{K}$} \\
\hline 273.2 & & & \\
\hline
\end{tabular}
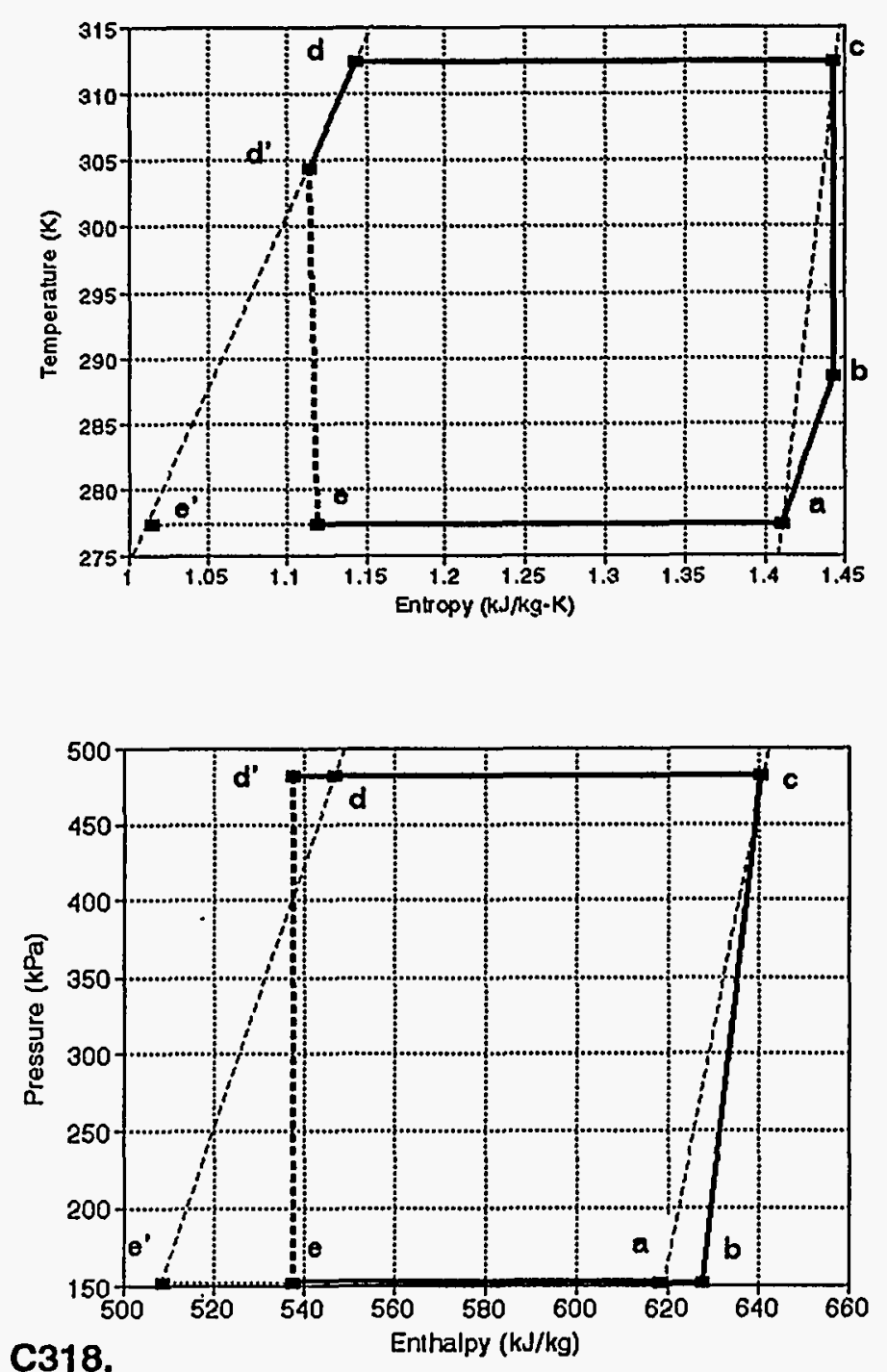

Figure 5-9: Analysis of Water-Chilling with Superheated C318. 
The result is a system that compresses without producing condensation and which has a COP 5\% higher than without the extra heat exchanger and correspondingly lower electric loads. To be sure this is a reasonable system; the required heat exchanger size should be determined.

The enthalpy differences between points "a" and " $b$ " and the rate of mass flow imply that the heat exchanger must transfer $53 \mathrm{~kW}$ of thermal energy between the two streams in icebuilding operation, and $61 \mathrm{~kW}$ in water-chilling operation. The latter is the more demanding case for the heat exchanger, with a log mean temperature difference of $25^{\circ} \mathrm{C}$ requiring a heat exchanger with "UA" equal to $2.5 \mathrm{~kW} / \mathrm{m}^{2}$. The ice building mode requires has an LMTD of $30^{\circ} \mathrm{C}$ and requires " $\mathrm{UA}$ " only equal to $1.8 \mathrm{~kW} / \mathrm{m}^{2}$. In either case, the heat exchanger is quite modest for a system of this size, and will have a small effect on total cost.

The result is a system which appears practical and which, we will see in the next chapter, will be much less expensive to construct due to the reduced pressure requirements. Clearly many questions about R-C318 remain to be answered, but the technical promise of the refrigerant seems substantial. 


\section{SYSTEM COST ESTIMATES}

Here we integrate the operational data of the previous sections to derive life-cycle costs for a thin polymer ice making system based on the use of compression refrigerants in the polymer evaporator. The approach and economic parameters will be taken from our previous economic assessment ${ }^{2}$, and we will continue to work in the early 1992 dollars employed there to permit direct comparisons. The reader can estimate costs in current (1995) dollars by increasing the numbers presented here by $6 \%^{30}$.

In Section 4 we developed component sizes based on the requirements of our economic assessment. We also continue to use the electric rate structure presented in the economic assessment, which we repeat in Table 6-1 for reference. The rates are high compared to U.S. national averages, but it is in just such locations that cold storage is most attractive.

\subsection{Cost Estimates with R-134a}

Table 6-1 Electricity Rate Structure.

\begin{tabular}{||c|c|c|}
\hline & \multicolumn{1}{|c|}{$\begin{array}{c}\text { Demand } \\
(\$ / \mathrm{Kw})\end{array}$} & $\begin{array}{c}\text { Energy } \\
(\boldsymbol{\phi} / \mathrm{kWhr})\end{array}$ \\
\hline $\begin{array}{l}\text { Off-Peak } \\
\text { 00:00-07:00 }\end{array}$ & 0.00 & 7.00 \\
\hline $\begin{array}{l}\text { On-Peak } \\
\text { 10:00-22:00 } \\
\text { (Mon-Sat) }\end{array}$ & 20.25 & 9.84 \\
\hline $\begin{array}{l}\text { Intermediate } \\
\text { (All Other } \\
\text { hours) }\end{array}$ & 4.83 & 8.61 \\
\hline Service: & $\$ 1.00$ per day \\
\hline
\end{tabular}

We then prepared a list of materials for the R-134a ice maker itself, presented in Table 6-2. The costs are largely from construction estimating handbooks ${ }^{31}$, updated to 1992 using the capital goods price inflator ${ }^{30}$.

Since we need a total area of $185 \mathrm{~m}^{2}\left(1991 \mathrm{ft}^{2}\right.$ ) (from Table 5-1) and since each pad has a heat exchange area of $10.8 \mathrm{ft}^{2}, 184$ pads are needed. The PFA film is seen to be a relatively small part of the total cost, indicating that there is little to be gained by trying to use some less expensive polymer, which would risk lowering system reliability. The header/support structure is complex, involving 68 tee's for each pad as well as the narrow tube which distributes refrigerant down the length of the evaporator tube, and for costing purposes is assumed to be made of copper. It should be possible to mass-produce these headers (one for each side) from some less expensive material, which could lower the cost of the pads substantially, but we have not assumed that here. Rather, we have treated the entire job as a custom plumbing installation, taking the costs from the estimating handbooks ${ }^{31}$. Since the pads would actually be assembled in a factory and shipped to the job site, we have compensated for this over-estimate by not charging mark-ups ("general and administrative" or "overhead and profit") on these components.

The distribution piping is also complex, and again, we have used prices appropriate to copper. It should be possible to use aluminum, since it is quite corrosion-resistant at low temperatures, and this would lower the cost for materials by two-thirds. Again, these manifolds would be factory-assembled, so we have not charged mark-ups. 
Table 6-2: Component Costs for Polymer Film Ice Maker.

\begin{tabular}{|c|c|c|c|c|c|}
\hline Item & $\begin{array}{l}\text { Quantity } \\
\text { /Size } \\
\end{array}$ & Units & $\begin{array}{l}\text { Unit Cost } \\
\text { (\$/unit) }\end{array}$ & $\begin{array}{l}\text { Item } \\
\text { Cost(\$) }\end{array}$ & $\begin{array}{l}\text { System } \\
\text { Cost }(\$)\end{array}$ \\
\hline Pads: & 184 & & & & \\
\hline PFA Film & 12.9 & sf & 1.16 & 15 & \\
\hline Header/Support & 1 & & 56.00 & 56 & \\
\hline Check Valve & 1 & & 11.00 & 11 & \\
\hline Insulation & 4 & $\mathrm{ft}$ & 0.33 & 1 & \\
\hline Assembly & & & & 40 & \\
\hline Pad Total $=$ & & & & 123 & 22,632 \\
\hline \multicolumn{6}{|l|}{ Piping: } \\
\hline 1-1/4" Copper & $4 \times 40$ & $\mathrm{ft}$ & 12 & 1920 & \\
\hline 3" Copper & $4 \times 40$ & $\mathrm{ft}$ & 28 & 4480 & \\
\hline 1-1/4" Tees & 184 & & 35 & 6440 & \\
\hline 3" Tees & 184 & & 63 & 11,592 & \\
\hline Total: & & & & 24,432 & 24,432 \\
\hline $\begin{array}{l}\text { Compressor \& } \\
\text { Condenser: }\end{array}$ & $\begin{array}{r}142 \\
\text { (nominal) }\end{array}$ & tons & 84,870 & $+15 \% \mathrm{O} \& \mathrm{P}$ & 97,600 \\
\hline $\begin{array}{l}\text { ICE MAKER } \\
\text { TOTAL: }\end{array}$ & & & & & 144,664 \\
\hline
\end{tabular}

The cost of the compressor/water cooled condenser combination was obtained from the cost of an efficient water-cooled water chiller ${ }^{32}$ by taking a $\$ 10,000$ credit for the un-needed evaporator; here the recommended $15 \%$ mark-up was added.

The four tanks, described in Appendix B, are quite large and it may be advisable to bury them, leaving access space at one end. Means reports buried 30,000 gallon tank costs (with three-eighths inch walls and galvanic protection) which scale to ${ }^{92} \$ 36,800$ for 35,692 gallons. Including a 17\% recommended mark-up, the four tanks will then cost $\$ 173,064$, more than was estimated in our previous study. We use a previously-derived ${ }^{2} \$ 14,000$ capital cost for the cooling tower, and assume (as there) that $10 \mathrm{~kW}$ of auxiliary power is required for the cooling tower itself. 
These costs are combined with the electric rates above to obtain life-cycle costs and the net present value of operating this system. The details are in Appendix F, where ongoing operating costs are converted to a present value using a $6 \%$ per year discount rate. The calculations in Appendix $\mathrm{F}$ assume twenty-four hour per day operation of the system with eight hours per day in water chilling mode, which occurs during the time of peak electric rates. (The electric rate structure is embedded in the spreadsheet.) The power needed to distribute the refrigerant around the system, calculated in Appendix D as 259 watts for water chilling and 199 watts for ice making is added to the $10 \mathrm{~kW}$ needed for the cooling tower. Maintenance is charged out at $\$ 1000$ per month, including repairs and replacements.
Table 6-3: Economic Characteristics of the Polymer Ice Maker, R-134a.

\begin{tabular}{||l|c|}
\hline \multicolumn{2}{||l|}{ CAPITAL COSTS } \\
\hline Ice Maker $(\$ 1000):$ & 145 \\
\hline Installation $(\$ 1000):$ & $($ Inc.) \\
\hline Tank $(\$ 1000):$ & 173 \\
\hline Tower (\$1000): & 14 \\
\hline OPERATING COSTS \\
\hline Electricity (\$/mnth): & 4269 \\
\hline Maintenance (\$/mnth): & 1000 \\
\hline PRESENT VALUE \\
\hline (Over 5 yrs, \$1000): \\
\hline
\end{tabular}

These results are summarized in Table 6-3 and compared to the competition in the Summary. The thin polymer ice maker used directly as the evaporator of the R-134a based compression chiller certainly seems to offer substantial technical and economic advantages over existing systems.

\subsection{Cost Estimates with R-C318}

Our treatment of the R-C318 based system parallels that of the R134a system closely. Table 6-2 still describes the ice maker itself and the compressor and condenser and is still, we believe, quite conservative in assuming the entire apparatus is constructed as a piecework copper plumbing job, rather than in a factory from less expensive materials such as aluminum. One might question whether the more than doubled displacement required by the R-C318 would not lead to higher costs for the compressor, but the power requirements have only increased by $10 \%$. Further, although a greater volume of refrigerant must be moved, the peak pressures are half those in the R-134a system, so many construction constraints can be relaxed.

The remaining economic characteristics are detailed in Appendix $G$ and summarized in Table 6-4. The major item is the tank cost. We used an estimate of $\$ 132 \mathrm{k}$ in our previous study $^{2}$, taken from a well-documented real system ${ }^{33}$. We here assume that the minor pressurization (comparable to that in an inflatable tennis arena) can be accomplished by strengthening and sealing that structure, and simply increase the cost by $10 \%$ to represent this modest additional work. The result, $\$ 145 \mathrm{k}$, is substantially below the cost of the pressurized system required by the use of R-134a. 
Other characteristics of the R-C318 system are transferred into Appendix $G$ as they were in the previous case, and the resulting net present value, $\$ 457 \mathrm{k}$, is sufficiently less than that of R-134a and of the available commercial units to merit considerable continued investigation.
Table 6-4: Economic Characteristics of the Polymer Ice Maker, R-C318.

\begin{tabular}{|l|c|}
\hline \multicolumn{2}{|l||}{ CAPITAL COSTS } \\
\hline Ice Maker $(\$ 1000):$ & 145 \\
\hline Installation $(\$ 1000):$ & $($ Inc.) \\
\hline Tank $(\$ 1000):$ & 145 \\
\hline Tower $(\$ 1000):$ & 14 \\
\hline OPERATING COSTS \\
\hline Electricity (\$/mnth): & 4476 \\
\hline Maintenance (\$/mnth): & 1000 \\
\hline PRESENT VALUE \\
\hline (Over 5 yrs, \$1000): \\
\hline
\end{tabular}




\section{REFERENCES}

1. R. W. Leigh, "Thin Polymer Icemaker Development and Test Program: Final Report on Technology", BNL-47549, Brookhaven National Laboratory, Upton NY 11973 (1991).

2. R. W. Leigh, "Economic Assessment of Thin Polymer Ice Maker", BNL-48103, Brookhaven National Laboratory, Upton NY 11973 (1992)

3. ASHRAE 1989 Handbook of Fundamentals (I-P Edition), Table 1, p. 16.3, American Society of Heating, Refrigerating and Air Conditioning Engineers, 1791 Tullie Circle NE, Atlanta GA 30329 (1989)

4. C. R. Miro and J. E. Cox, "Montreal Protocol Revised in Copenhagen", ASHRAE J., Feb. 1993, p. 14.

5. T.E.Daubert \& R.P.Danner, "Physical and Thermodynamic Properties of Pure Chemicals: Data Compilation", Hemisphere Publishing, New York, 1991.

6. "ASME Boiler and Pressure Vessel Code", Section 8, American Society of Mechanical Engineers, New York NY, 1992.

7. R. A. McCarthy, "Chemically Resistant Polymers" in The Encyclopedia of Polymer Science, 2nd edition, Vol 3, p. 421, J. Wiley \& Sons, New York 1985.

8. "Engineering Data Bank: Films: Modern Plastics Encyclopedia 1986-87, Joan Agranoff, ed., McGraw-Hill, New York.

9. R.W.Leigh, H.S.Isaacs, J. Kirley, J.G.Murray and A. Ravve, "Cost Reductions in Absorption Chillers, Phase II", BNL 42502, Brookhaven National Laboratory, Upton NY 11973 (1989).

10. ASHRAE, ibid, p. 16.6

11. R. G. Richard and I. R. Shankland, "Flammability of Alternative Refrigerants", ASHRAE J., April 1992, p. 20.

12. ASHRAE, ibid, p. 16.9

13. ASHRAE, ibid, Table 12, p. 16.9

14. M. Sittig, "Handbook of Toxic and Hazardous Chemicals and Carcinogens", Noyes Publications, Park Ridge NJ, 1991.

15. D.P. Wilson and R. S. Basu, "Thermodynamic Properties of a new Stratospherically Safe Working Fluid-Refrigerant 134A", ASHRAE Transactions, Vol. 94 pt. 2, p. 2095 (1988). 
16. ASHRAE 1993 Handbook of Fundamentals (S-I Edition), p. 17.29, American Society of Heating, Refrigerating and Ventilating Engineers, 1791 Tullie Circle NE, Atlanta GA 30329 (1993).

17. R. Cipollone, "Thermodynamic Properties of Perfluorocyclobutane", ASHRAE Trans., Vol. 97, pt. 2, p. 3517 (1991).

18. T. E. Morsey, "Extended Benedict-Webb-Rubin Equation of State: Application to Eight Fluorine Compounds", J. Chem. \& Eng. Data, Vol. 15, No. 2, p. 256 (1970).

19. J. J. Martin, "Thermodynamic Properties of Perfluorocyclobutane", J. Chem. \& Eng. Data, Vol 7, p. 68 (1962).

20. R.W.Leigh, H.S.Isaacs et.al., op. cit., Table 1-3.

21. Marks' Standard Handbook for Mechanical Engineers, 8th edition, T. Baumeister, ed., McGraw-Hill, New York, 1979, p. 6-27.

22. ASHRAE, ibid, p. 1.11

23. ASHRAE, ibid, p. 1-4

24. S. Corr, T.W.Dekleva and A. L. Savage, "Retrofitting Large Refrigeration Systems with R-134a", ASHRAE J., Feb. 1993, p. 29.

25. S. J. Eckels, T. M. Doerr and M. B. Pate, "In-Tube Heat Transfer and Pressure Drop of R-134a and Ester Lubricant Mixtures in a Smooth Tube and a Micro-Fin Tube: Part 1 Evaporation", ASHRAE Trans. V. 100, Pt 2, p. 265 (1994).

26. R. W. Leigh, D. W. Huszagh, J. G. Murray, A. Ravve, J. H. Saunders, H. Teoh and W. G. Wilhelm, "Cost Reductions in Absorption Chillers, Final Report (June 1984-May 1985)", BNL 38345, Brookhaven National Laboratory, Upton NY 11973 (1986), Tables 3-3 and 3-4, evaporator.

27. ASHRAE, Ibid, Fig 11, p. 3.14

28. ASHRAE, Ibid, p. 49 , eq. 5 using the average of results for R-12 and R-22.

29. Ref. 3, p. 16.8, Tables 9, 10 and ASHRAE 1985 Handbook of Fundamentals (S-I Edition), Table 6, p. 17.15, American Society of Heating, Refrigerating and Air Conditioning Engineers, 1791 Tullie Circle NE, Atlanta GA 30329 (1989).

30. U.S. Dept. of Commerce, "Statistical Abstract of the United States -1994", U.S. Government Printing Office, p. 496 (Producer Price Index - Capital Goods) and New York Times, 11 January 1995. 
31. "Means Mechanical Cost Data", Robert Snow Means Co., Kingston MA, 02364 (1985).

32. Means, op. cit., 15.7, line 158.

33. C. M. Landry and C. D. Noble, "Making Ice Thermal Storage First-Cost Competitive", ASHRAE Journal 33, No. 5, p. 19 (May 1991). 


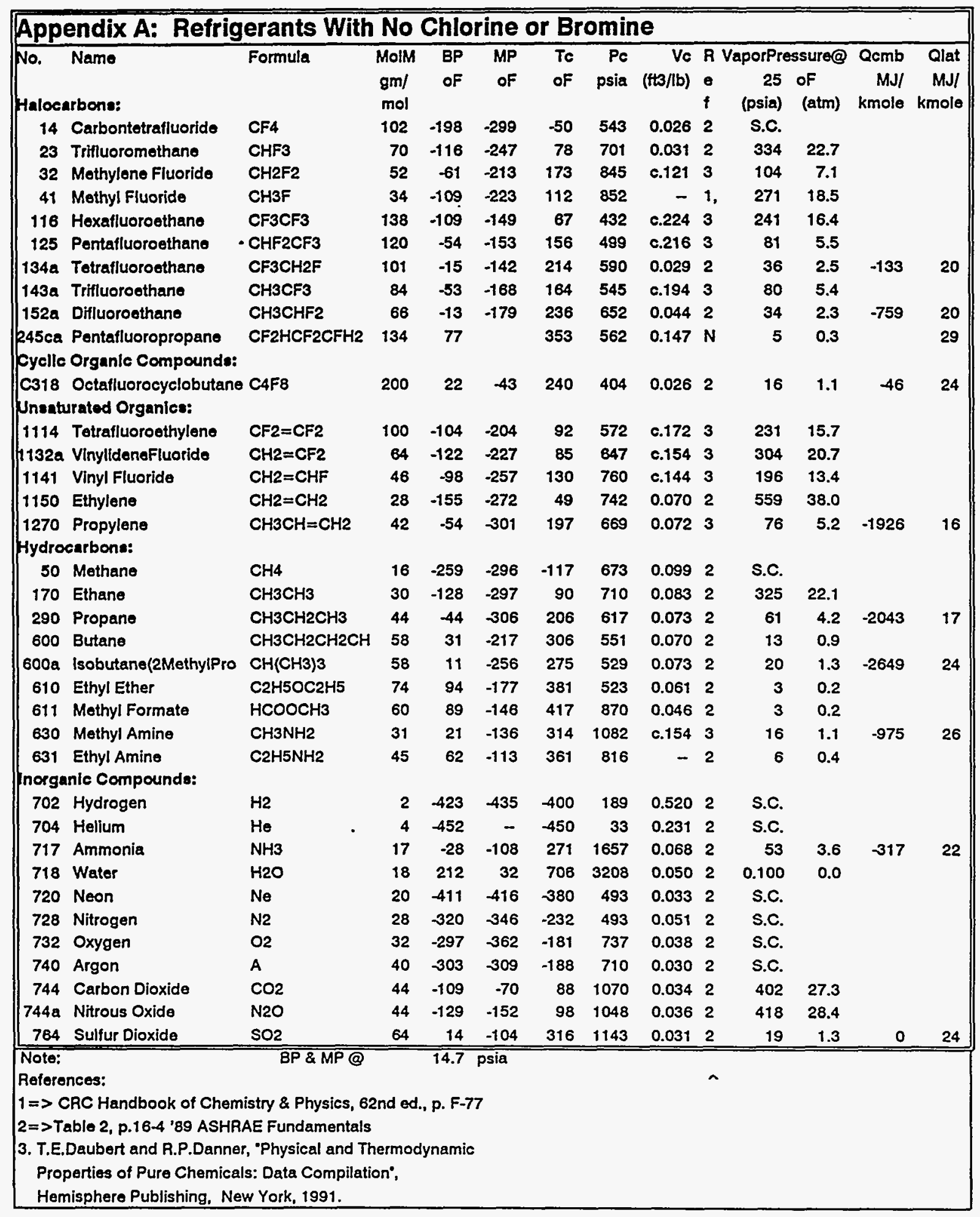





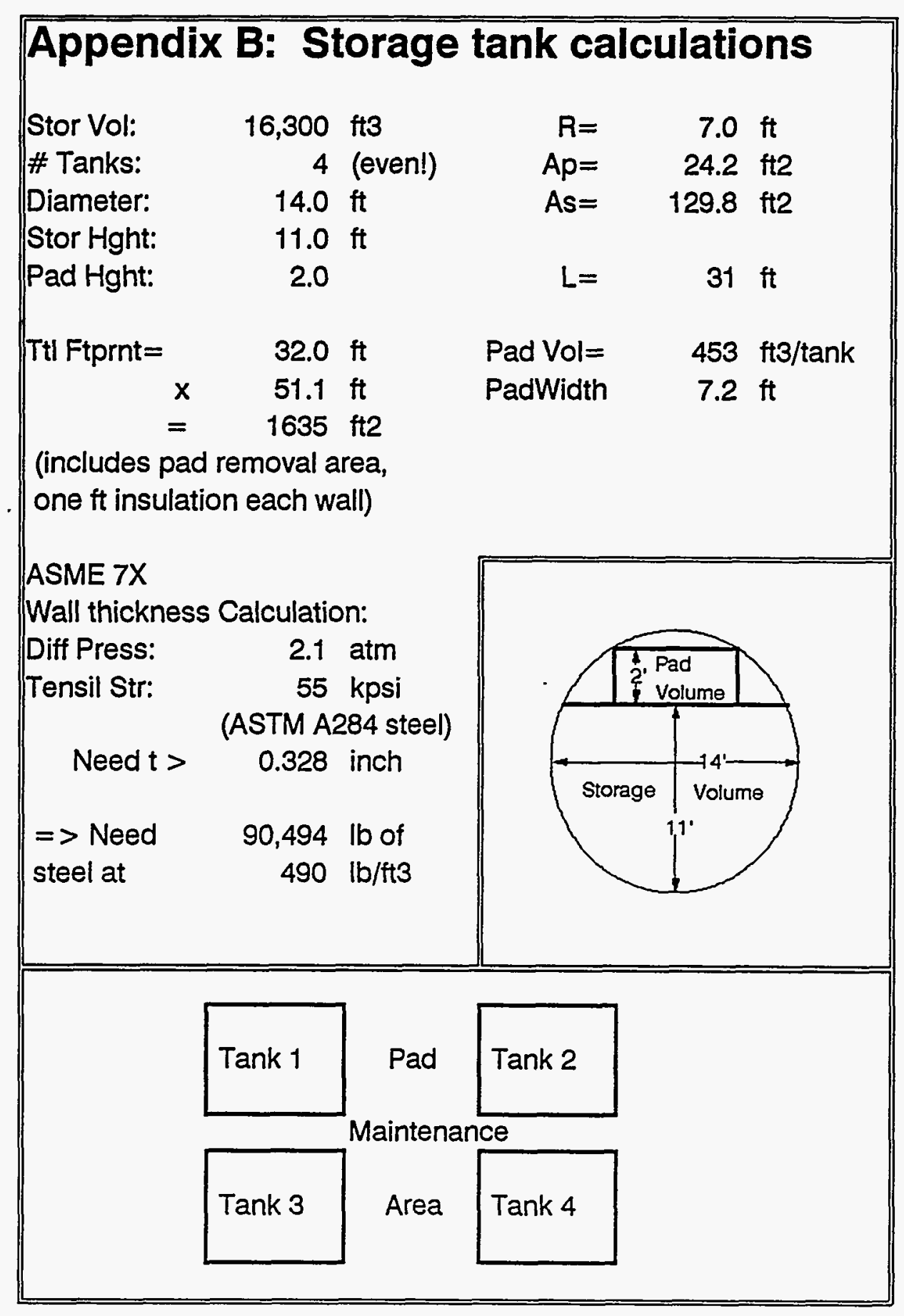



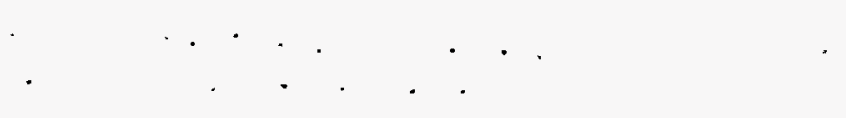

.

1

$\ldots$

:

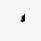

.

. 


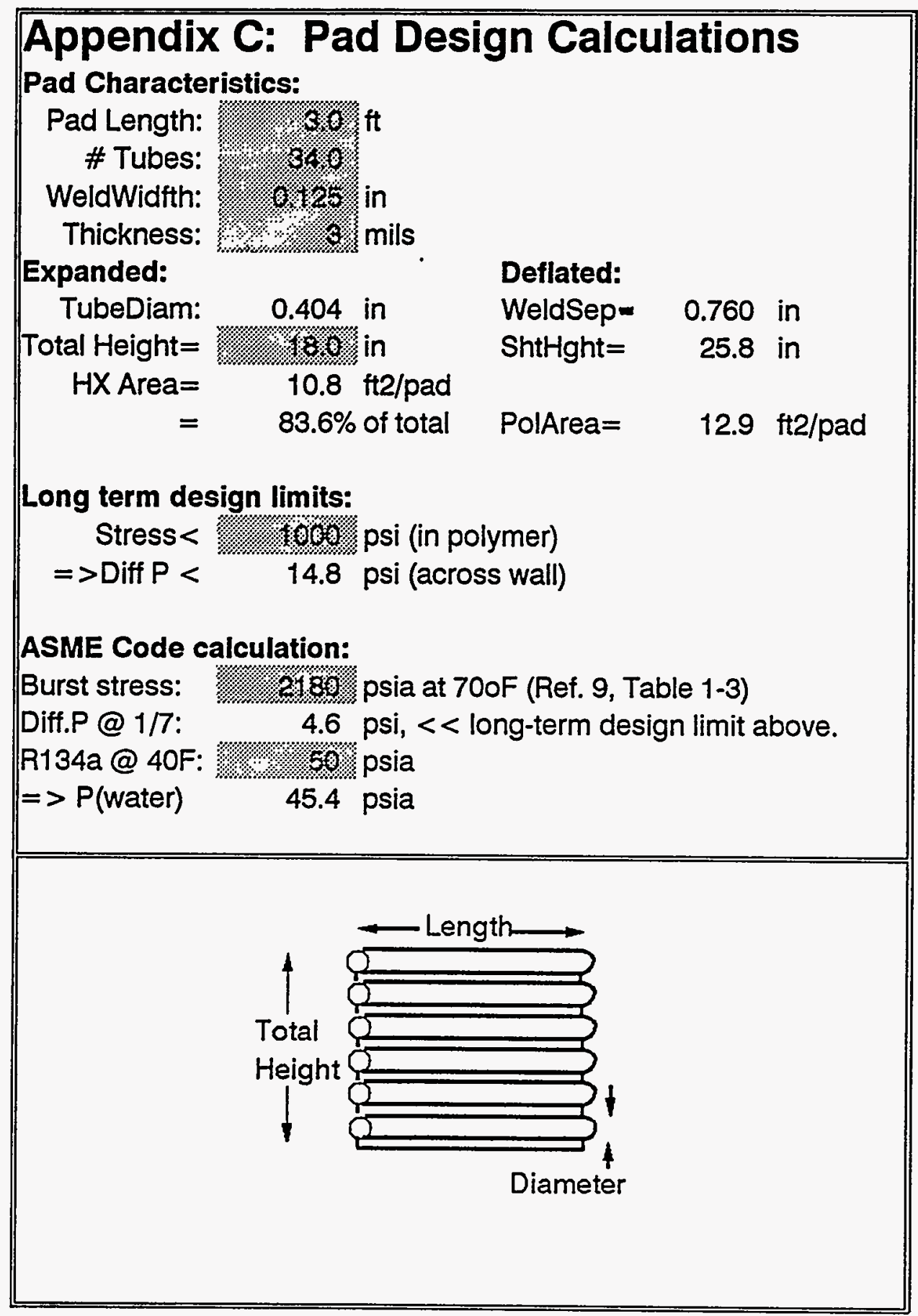




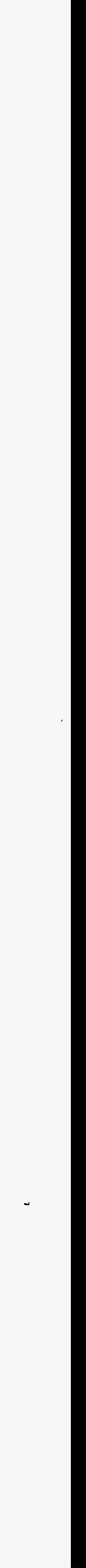




\begin{tabular}{|c|c|c|c|c|c|c|}
\hline Appendix D: & Pipe Si & izing $\mathrm{C}$ & alculatic & Ons fol & R-13 & \\
\hline System Mass flow: & \% \% & $\mathrm{kg} / \mathrm{s}$ & Water Chilli & ing at $T=$ & & OC \\
\hline Volume Flow with & \% & flash not $c$ & irculated. I & Density & & Viscosity \\
\hline Liquid: $\quad 2.00$ & $1 / s=$ & 31.7 & $\mathrm{gal} / \mathrm{min} @$ & \%1 & $\mathrm{kg} / \mathrm{liter}$ & $4 \%$ \\
\hline Vapor: & $1 / \mathrm{s}=$ & 334 & $\mathrm{cfm} @$ & 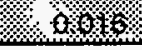 & $\mathrm{kg} / \mathrm{itter}$ & $4756+15$ \\
\hline Distribution & & & & & & Pa-s \\
\hline \# of sub-systems: & 4 & tanks & & & & \\
\hline Pipe Length: & 12.2 & $m=$ & $1 \% 1 \%$ \%ox & $\mathrm{ft}$ & & \\
\hline Liquid pipe ID: & 3.175 & $\mathrm{~cm}=$ & 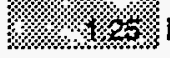 & in & & \\
\hline Liquid Fluid Vel= & 0.63 & $\mathrm{~m} / \mathrm{s}=$ & 2.07 & $\mathrm{ft} / \mathrm{s}$ & & \\
\hline Liq. Reynold's \#= & 183,570 & $f=$ & 0.0157 & & & \\
\hline Liq.Press. Drop = & 1.54 & $\mathrm{kPa}=$ & 0.224 & psi & & \\
\hline Liq. Pump Power= & 3.09 & $w=$ & 0.0041 & hp, total & & \\
\hline Vapor pipe ID: & 7.62 & $\mathrm{~cm}=$ & \% $8 \mathrm{k}$ & in & & \\
\hline Vapor Fluid Vel= & 8.64 & $\mathrm{~m} / \mathrm{s}=$ & 28.33 & $\mathrm{ft} / \mathrm{s}$ & & \\
\hline Vap. Reynold's \#= & 859,192 & $f=$ & 0.0119 & & & \\
\hline Vap.Press. Drop = & 1.15 & $\mathrm{kPa}=$ & 0.167 & psi & & \\
\hline Vap. Pump Power $=$ & 181.85 & $\mathbf{w}=$ & 0.2439 & hp, total & & \\
\hline Headers & & & & & & \\
\hline \# of sub-systems: & 80 & pads $=>$ & 46 & pads/tank & & \\
\hline Pipe Length: & 0.6 & $m=$ & 1.20 & $\mathrm{ft}$ & & \\
\hline Liquid pipe ID: & 0.3175 & $\mathrm{~cm}^{\prime}=$ & . 0 ot & in & & \\
\hline Llquid Fluid Vel= & 1.37 & $\mathrm{~m} / \mathrm{s}=$ & 4.50 & $\mathrm{ft} / \mathrm{s}$ & & \\
\hline Liq. Reynold's \#= & 39,907 & $\mathbf{f}=$ & 0.0224 & & & \\
\hline Liq.Press. Drop = & 5.20 & $\mathrm{kPa}=$ & 0.754 & psi & & \\
\hline Liq. Pump Power= & 10.40 & $w=$ & 0.013945 & hp, total & & \\
\hline Vapor pipe ID: & 1.27 & $\mathrm{~cm}=$ & \% & in & & \\
\hline Vapor Fluid Vel= & 6.76 & $\mathrm{~m} / \mathrm{s}=$ & 22.18 & $\mathrm{tt} / \mathrm{s}$ & & \\
\hline Vap. Reynold's \#= & 112,069 & $\mathrm{f}=$ & 0.0172 & & & \\
\hline Vap.Press. Drop = & 0.31 & $\mathrm{kPa}=$ & 0.045 & psi & & \\
\hline Vap. Pump Power = & 48.56 & $w=$ & 0.0651 & hp, total & & \\
\hline Tubes & & & & & & \\
\hline \# of sub-systems: & 1564 & tubes $<=$ & \% $34 \%$ & tubes/pad & & \\
\hline Pipe Length: & 0.9 & $m=$ & (1/. & $\mathrm{ft}$ & & \\
\hline Liquid pipe ID: & 0.16 & $\mathrm{~cm}=$ & 80000 & in & & \\
\hline Liquid Fluid Vel= & 0.65 & $\mathrm{~m} / \mathrm{s}=$ & 2.12 & $\mathrm{tt} / \mathrm{s}$ & & \\
\hline Liq. Reynold's \#= & 9,390 & $t=$ & 0.0321 & & & \\
\hline Liq.Press. Drop= & 4.96 & $\mathrm{kPa}=$ & 0.719 & psi & & \\
\hline Liq. Pump Power= & 9.92 & $w=$ & 0.0133 & hp, total & & \\
\hline Vapor pipe ID: & 1.03 & $\mathrm{~cm}=$ & 20,004 & in & & \\
\hline Vapor Fluid Vel= & 1.22 & $\mathrm{~m} / \mathrm{s}=$ & 4.00 & $\mathrm{ft} / \mathrm{s}$ & & \\
\hline Vap. Reynold's \#= & 16,317 & $\mathrm{f}=$ & 0.0280 & & & \\
\hline Vap.Press. Drop= & 0.03 & $\mathrm{kPa}=$ & 0.004 & psi & & \\
\hline Vap. Pump Power= & 4.75 & $w=$ & 0.0064 & hp, total & & \\
\hline System totals: & & & & & & \\
\hline Liq.Press. Drop= & 11.70 & $\mathrm{kPa}=$ & 1.697 & psi & & \\
\hline Liq. Pump Power= & 23 & $w=$ & 0.0314 & hp & & \\
\hline Vap.Press. Drop= & 1.49 & $\mathrm{kPa}=$ & 0.216 & psi & & \\
\hline Vap. Pump Power= & 235 & $w=$ & 0.3153 & $\mathrm{hp}$ & & \\
\hline Total Press.Drop = & 13.20 & $\mathrm{kPa}=$ & 1.914 & psi & & \\
\hline Total Pump Power $=$ & 259 & $w=$ & 0.3467 & $\mathrm{hp}$ & & \\
\hline
\end{tabular}





\begin{tabular}{|c|c|c|c|c|c|c|}
\hline Appendix E: & Pipe Si & zing $C$ & alculati & Ons for & $\mathbf{R - C}$ & 8 \\
\hline System Mass flow: & $8,6 \%$ & $\mathrm{~kg} / \mathrm{s}$ & Water Chill & ling at $T=$ & & $\mathrm{OC}$ \\
\hline Volume Flow with & \% 204 & flash not c & irculated. & Density & & Viscosity \\
\hline Liquid: $\quad 3.11$ & $\mathrm{I} / \mathrm{s}=$ & 49.3 & gal/min@ & \%॰ & $\mathrm{kg} / \mathrm{liter}$ & \%.7. \\
\hline Vapor: $\quad 354$ & $1 / s=$ & 750 & cfm @ & 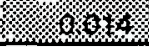 & $\mathrm{kg} / \mathrm{liter}$ & xyos \\
\hline Distribution & & & & & & Pa-s \\
\hline \# of sub-systems: & 4 & tanks & & & & \\
\hline Pipe Length: & 12.2 & $m=$ & \% & $\mathrm{ft}$ & & \\
\hline Liquid pipe ID: & 3.175 & $\mathrm{~cm}=$ & \% & in & & \\
\hline Liquid Fluid Vel= & 0.98 & $\mathrm{~m} / \mathrm{s}=$ & 3.22 & $\mathrm{ft} / \mathrm{s}$ & & . \\
\hline Liq. Reynold's \#= & 91,955 & $t=$ & 0.0182 & & & \\
\hline Llq.Press. Drop = & 5.33 & $\mathrm{kPa}=$ & 0.773 & psi & & $\bullet$ \\
\hline Liq. Pump Power = & 16.58 & $W=$ & 0.0222 & hp, total & & \\
\hline Vapor pipe ID: & 7.62 & $\mathrm{~cm}=$ & 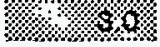 & in & & \\
\hline Vapor Fluid Vel= & 19.41 & $\mathrm{~m} / \mathrm{s}=$ & 63.68 & $\mathrm{ft} / \mathrm{s}$ & & \\
\hline Vap. Reynold's \#= & 1897352 & $f=$ & 0.0104 & & & \\
\hline Vap.Press. Drop = & 4.35 & $\mathrm{kPa}=$ & 0.631 & psi & & \\
\hline Vap. Pump Power = & 1539.99 & $W=$ & 2.0651 & hp, total & & \\
\hline Headers & & & & & & \\
\hline \# of sub-systems: & 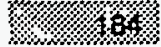 & pads $=>$ & 46 & pads/tank & & \\
\hline Pipe Length: & 0.6 & $\mathbf{m}=$ & 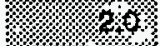 & $\mathrm{ft}$ & & \\
\hline Liquid pipe ID: & 0.3175 & $\mathrm{~cm}=$ & o. & in & & \\
\hline Liquid Fluid Vel= & 2.14 & $\mathrm{~m} / \mathrm{s}=$ & 7.01 & $\mathrm{ft} / \mathrm{s}$ & & \\
\hline Liq. Reynold's \#= & 19,990 & & 0.0266 & & & \\
\hline Liq.Press. Drop = & 18.44 & $\mathrm{kPa}=$ & 2.674 & psi & & \\
\hline Liq. Pump Power= & 57.38 & $W=$ & 0.076951 & hp, total & & \\
\hline Vapor pipe ID: & 1.27 & $\mathrm{~cm}=$ & \%ু & in & & \\
\hline Vapor Fluid Vel= & 15.19 & $\mathrm{~m} / \mathrm{s}=$ & 49.83 & $\mathrm{ft} / \mathrm{s}$ & & \\
\hline Vap. Reynold's \#= & 247,481 & $f=$ & 0.0148 & & & \\
\hline Vap.Press. Drop = & 1.14 & $\mathrm{kPa}=$ & 0.166 & psi & & \\
\hline Vap. Pump Power = & 404.44 & $W=$ & 0.5424 & hp, total & & \\
\hline Tubes & & & & & & \\
\hline \# of sub-systems: & 1564 & tubes $<=$ & পুy. & tubes/pad & & \\
\hline Pipe Length: & 0.9 & $m=$ & $2 \%$ & $\mathrm{ft}$ & & \\
\hline Liquid pipe ID: & 0.16 & $\mathrm{~cm}=$ & $0,0 x$ & in & & \\
\hline Liquid Fluid Vel= & 1.01 & $\mathrm{~m} / \mathrm{s}=$ & 3.30 & $\mathrm{ft} / \mathrm{s}$ & & \\
\hline Liq. Reynold's \#= & 4,704 & $f=$ & 0.0382 & & & \\
\hline Liq.Press. Drop= & 17.59 & $\mathrm{kPa}=$ & 2.551 & psi & & \\
\hline Liq. Pump Power $=$ & 54.74 & $W=$ & 0.0734 & hp, total & & \\
\hline Vapor pipe ID: & 1.03 & $\mathrm{~cm}=$ & $\% 0,008$ & in & & \\
\hline Vapor Fluid Vel= & 2.74 & $\mathrm{~m} / \mathrm{s}=$ & 8.98 & $\mathrm{ft} / \mathrm{s}$ & & \\
\hline Vap. Reynold's \#= & 36,034 & $\mathrm{f}=$ & 0.0230 & & & \\
\hline Vap.Press. Drop= & 0.11 & $\mathrm{kPa}=$ & 0.015 & psi & & \\
\hline Vap. Pump Power= & 37.72 & $w=$ & 0.05066 & hp, total & & \\
\hline System totals: & & & & & & \\
\hline Liq.Press. Drop= & 41.35 & $\mathrm{kPa}=$ & 5.997 & psi & & \\
\hline Liq. Pump Power= & 129 & $W=$ & 0.1726 & hp & & \\
\hline Vap.Press. Drop= & 5.60 & $\mathrm{kPa}=$ & 0.812 & psi & & \\
\hline Vap. Pump Power= & 1982 & $W=$ & 2.6581 & $h p$ & & \\
\hline Total Press.Drop= & 46.95 & $\mathrm{kPa}=$ & 6.809 & psi & & \\
\hline Total Pump Power= & 2111 & $\mathrm{~W}=$ & 2.8307 & $h p$ & & \\
\hline
\end{tabular}




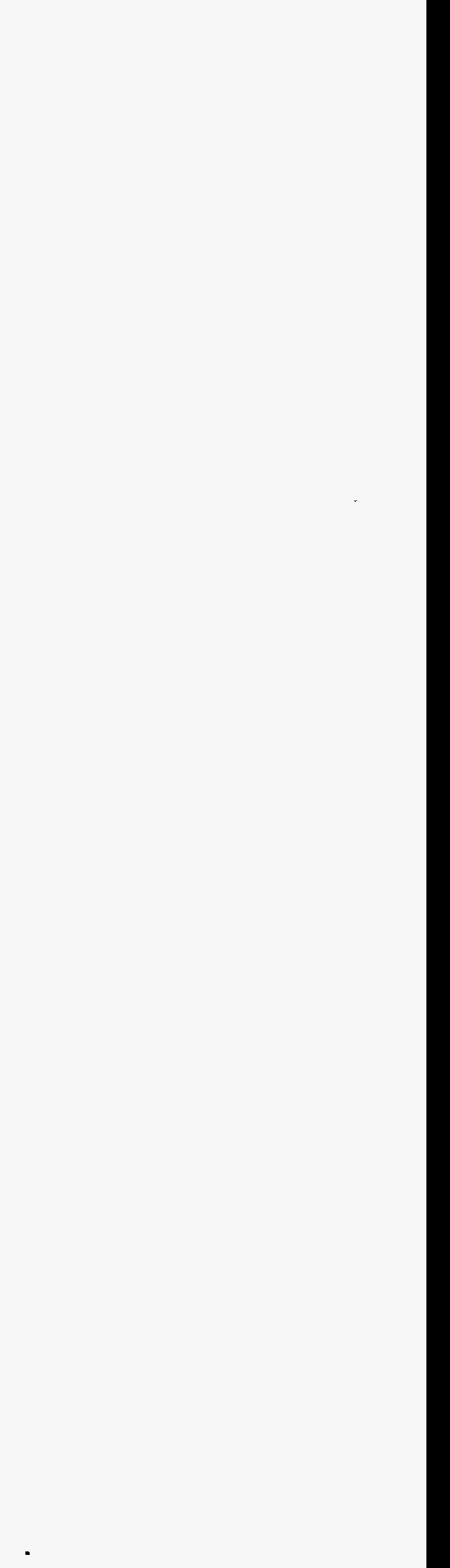




\begin{tabular}{|c|c|c|c|c|c|c|c|}
\hline \multicolumn{8}{|c|}{ Appendix F: Economic Analysis for R-134a } \\
\hline \multicolumn{8}{|c|}{ Tank Capacity: } \\
\hline & $\mathrm{Ice}=$ & 5519 & ton-hrs = & 7998 & $\mathrm{ft3}$ of ice & \multirow{2}{*}{\multicolumn{2}{|c|}{$\begin{array}{l}.49 \% \text { ice } \max \\
3.0 \mathrm{ft} 3 / \mathrm{tn}-\mathrm{hr}\end{array}$}} \\
\hline & Volume $=$ & 142,656 & gallons $=$ & 19123 & $\mathrm{ft} 3$ in tank & & \\
\hline \multicolumn{8}{|c|}{ Ice Maker Capacity: } \\
\hline & Production $=$ & 116 & tons/day & & & & \\
\hline & $\begin{array}{c}\text { Capacity }= \\
=\end{array}$ & $\begin{array}{r}9635 \\
116\end{array}$ & $\begin{array}{l}\text { lbs/hr, } \\
\text { tons }\end{array}$ & 24 & hrs/day & & \\
\hline \multirow{3}{*}{ Power: } & Compressor: & 0.73 & $\mathrm{~kW} /$ ton or & 0.61 & \multirow{2}{*}{\multicolumn{2}{|c|}{$\begin{array}{l}\mathrm{kW} / \text { ton as chiller for } \\
\mathrm{kW} \text { as chiller }\end{array}$}} & $\mathrm{hr} / \mathrm{day}$ \\
\hline & Auxiliary: & 10199 & kW or & $\sqrt{0.259}$ & & & \\
\hline & Total $=$ & 0.818 & $\mathrm{~kW} / \mathrm{ton}$ or & 0.699 & \multicolumn{2}{|c|}{$\mathrm{kW} /$ ton as chiller } & \\
\hline \multicolumn{8}{|c|}{ Economics: } \\
\hline & Ice Maker= & $\$ 144,664$ & or & $\$ 1,251$ & /ton & & \\
\hline & Tank Cost $=$ & 173,064 & or & $\$ 9.05$ & $/ \mathrm{ft3}$ & & - \\
\hline & Cool Tower= & 14,369 & & & & & \\
\hline \multirow[t]{4}{*}{5} & $-y r$ electric $=$ & 97,381 & based on & $\$ 2,373$ & demand & $\$ 4,269$ & energy monthly \\
\hline & + Maintenance & 50,548 & & $\$ 1,000$ & /month & & \\
\hline & Discounted @ & \multicolumn{2}{|c|}{$6 \% /$ year } & & & & \\
\hline & TotalPV $(\$ 1000)$ & \multicolumn{2}{|c|}{480} & & & & \\
\hline
\end{tabular}





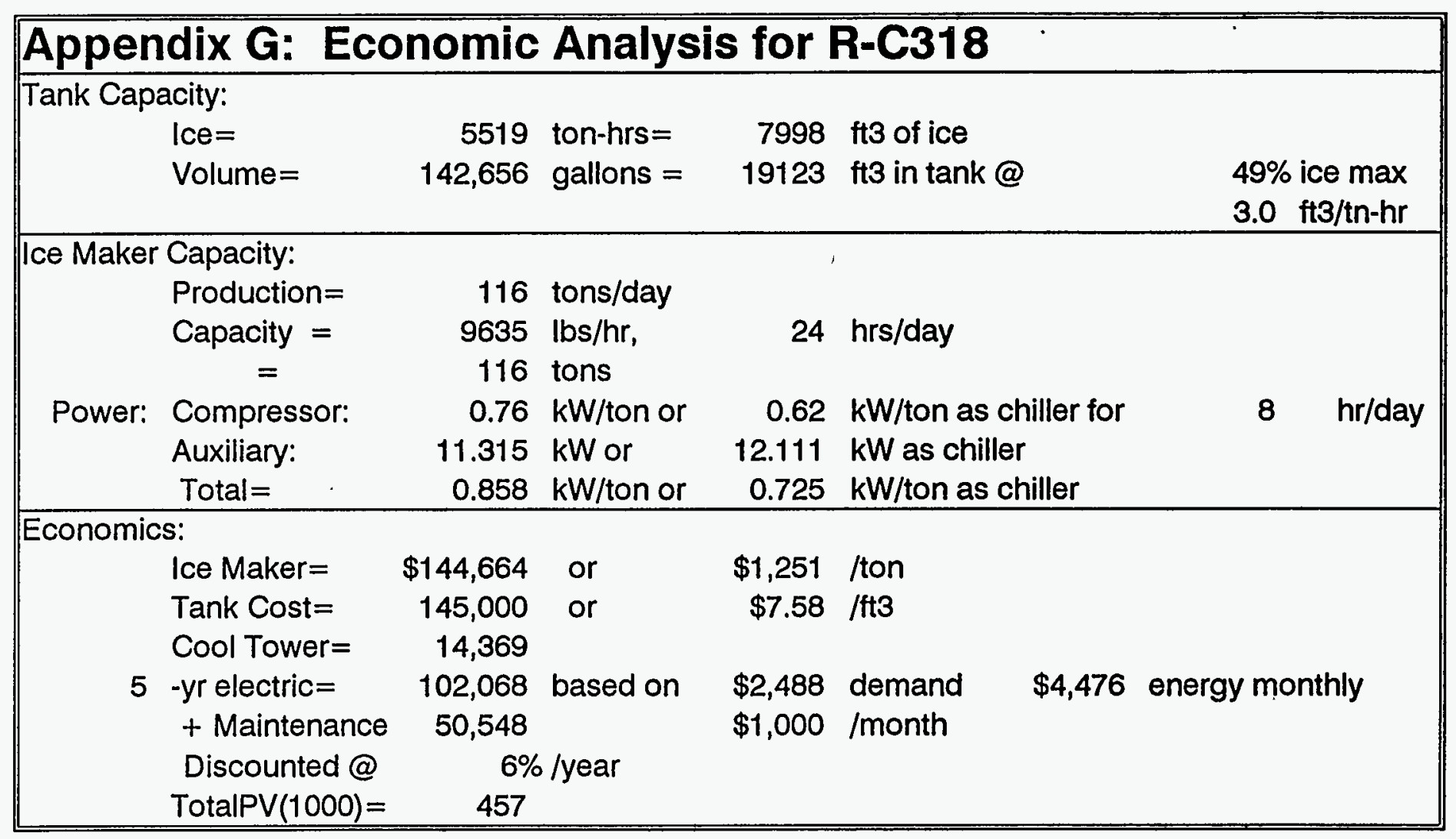


